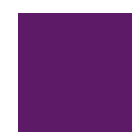

\title{
Lodz
}

Economics

Working

Papers

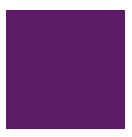

REGIONAL EFFECTIVENESS OF INNOVATION - LEADERS AND FOLLOWERS OF THE EU NUTS $\theta$ AND NUTS 2 REGIONS

\author{
Agata Żółtaszek \\ Alicja Olejnik
}


Agata Żółtaszek, Alicja Olejnik

The Faculty of Economics and Sociology,

University of Lodz

\section{Regional effectiveness of innovation - leaders and followers of the EU NUTS 0 and NUTS 2 regions}

\section{Abstract}

Innovation constitutes an important factor for growth in all EU countries. Regions of the EU play a principle role in shaping new innovation trajectories and in bringing out the hidden potential for national growth. However, it is not only the level of innovation that diversifies regions, but also the innovative potential and the level of its realization. Therefore, the aim of this paper is to assess the realization of innovative potential, defined as effectiveness, in EU NUTS 0 and, if possible, NUTS 2 regions. To accomplish this goal a relative effectiveness method in used. The DEA (Data Envelopment Analysis) makes it possible to analyse the relative technical effectiveness based on regional inputs and outputs, without incorporating the legal and technological specifications of innovations, thus treating it like a production process. The inputs of the process are employment in technology and knowledge-intensive sectors and R\&D expenditure, while the outputs include the number of patents and GDP. All variables are standardized by the size of the economically active population. DEA results divide regions in to two groups - effective, being the leaders; and ineffective, or followers. The DEA approach was combined and extended by ESDA (Exploratory Spatial Data Analysis) in order to pinpoint spatial patterns of innovation efficiency across NUTS 2 regions. Defining the best practices and implementing the learning-from-the-best policy is important in the process of regional development and specialization.

Key words: regional innovation, effectiveness, DEA (data envelopment analysis), regional development, spatial autocorrelation, ESDA (exploratory spatial data analysis)

JEL: C44, C46, C38, O31,O11 


\section{Introduction}

According to the OECD, "An innovation is the implementation of a new or significantly improved product (good or service), or process, a new marketing method, or a new organisational method in business practices, workplace organisation or external relations. (OECD and Eurostat, Guidelines for collecting and interpreting innovation data, 2005). In this sense innovation thus constitutes a foundation for creating new enterprises, helps in job creation and, as a result, is a key factor in economic growth. For years now, the relationship between innovation and economic development, as well as productivity, has been widely acknowledged. Innovation reveals its usefulness in addressing selected social and global challenges, such as demographic changes, threats of epidemics, and even climate change. Efficiency, flexibility and strength are the main features that characterize an innovative economy. Therefore strengthening innovation is a key challenge for all EU countries and regions on their path to prosperity and, as a result, a better life.

Today, the great part of economic growth is still due to the replication of existing technologies through investment and expansion of the labour force. However while innovation still contributes only slightly to economic growth, this input is vital to attain a better standard of living in the EU. Therefore, recognition of the innovation indicators is key for benchmarking national performance as well as for comparison of local innovation performance at the regional level and its influence on economic development.

In light of the above, the aim of this paper is to assess the realization of innovative potential, measured as effectiveness or efficiency in European states (NUTS 0) and provinces (EU NUTS 2) using DEA (Data Envelopment Analysis). The DEA approach treats regions (countries and provinces) as "factories of innovation", where financial resources and human capital is transformed into patents and, indirectly, to economic development, i.e. GDP. Results of the analysis make it possible to identify the leaders, who realize their full innovative potential, and followers - regions that underachieve.

Innovations strongly depend on creativity, which cannot be measured in macro-scale, hence in order to introduce the approximation of it to the research, the DEA model with variable returns (or economies) of scale is incorporated. This makes it possible to assess the reaction of innovation outputs to a marginal change of inputs. In order to analyse the regional effectiveness of innovation, the DEA approach on efficiency was combined with spatial statistical tools for autocorrelation. This makes it possible to highlight clusters of regions (NUTS 2) with similar levels of innovation efficiency. 
In Section 2 we briefly set out the methods of Data Envelopment Analysis, together with its aims and assumptions. Section 3 presents input and output variables with data description. Section 4 gives detailed empirical results for 28 EU countries in 2000-2014 and for EU NUTS 2 in 2012. Furthermore, the spatial pattern of innovation efficiency is examined using ESDA (Exploratory Spatial Data Analysis). Spatial autocorrelation of the efficiency across NUTS 2 regions makes it possible to distinguish clustered innovation efficiency, i.e. hot- and coldspots. The major implications of the results are presented in Section 5, which additionally offers a summary and some closing remarks.

\section{Methodology}

Data Envelopment Analysis (DEA), introduced by Charnes, Cooper, and Rhodes in 1978, is based on the idea that the process of production, literal or figurative, performed by numerous objects (Decision Making Units - or DMU(s)) has a frontier or border of maximal effectiveness. Some DMUs fully realize their capabilities, transforming their available inputs (resources) into achievable outputs (results, effects). The efficiency or effectiveness frontier is stretched across these effective DMUs and the linear combination of their coordinates in a multidimensional space ( $\boldsymbol{R}^{S+M}$, where $S$ is the number of outputs, $M$ is the number of inputs). All inefficient objects are below the frontier and aspire to achieve it, as they do not utilize their full production potential. The DEA approach is based on effectiveness, defined as the relationship of synthetic output (calculated as a weighted sum of results) to a synthetic input (as a weighted sum of resources). This effectiveness $\theta$ is limited to a $[0,1]$ interval, where 1 means $100 \%$ effectiveness and $(1-\theta) \cdot 100 \%$ is the amount of inefficiency. (Charnes, Cooper, Rhodes 1978, pp. 430-440; Gospodarowicz 2000, pp. 240-246)

The effectiveness of $k$-th $(k=1, \ldots, N)$ DMU (Decision Making Unit) with $S$ outputs and $M$ inputs can be presented as follows (Gospodarowicz 2002, pp.57-70):

$$
\theta_{k}=\frac{\sum_{r=1}^{S} \mu_{r k} y_{r k}}{\sum_{i=1}^{M} v_{i k} x_{i k}}
$$

$y_{r k^{-}}-r$-th output of $k$-th DMU, $r=1, \ldots, S, x_{i k^{-}} i$-th input of $k$-th DMU, $i=1, \ldots, M, \mu_{r k}-$ weight for $r$-th output of $k$-th DMU, $v_{i k}$ - weight for $i$-th input of the $k$-th DMU.

Basically, DEA maximizes effectiveness (1) for each DMU with respect to $\boldsymbol{\mu}$ and $\boldsymbol{v}$ parameters. This optimization is performed under the restriction that with the parameters used for any $\operatorname{DMU} j(j=1, \ldots, N)(2)$ effectiveness is bound to $[0,1]$, as follows:

$$
\frac{\sum_{r=1}^{S} \mu_{r k} y_{r j}}{\sum_{i=1}^{M} v_{i k} x_{i j}} \leq 1
$$


as well as non-negative values of the weights $\left(\mu_{r k} \geq 0, v_{i k} \geq 0\right)$. Additionally, let all $x_{i k}$ and $y_{r k}$, for $k \leq N, r \leq S, i \leq M$, be nonnegative $\left(y_{r k} \geq 0, x_{i k} \geq 0\right)$. Let us also assume the existence of at least one input and one output with non-zero value $\left(\forall_{1 \leq k \leq N}\left(\exists_{1 \leq r \leq s} y_{r k}>0 \wedge\right.\right.$ $\left.\exists_{1 \leq i \leq M} x_{i k}>0\right)$ ).

In this analysis a DEA BCC output-oriented model is used. (Charnes, Cooper, Golany, Seinford, 1997:31-36; Gospodarowicz, 2000:36-39; Toloo, Nalchigar, 2009: 598-599). In a linearized form this model can be presented in primal form as:

$$
\begin{gathered}
\max _{\boldsymbol{\theta}, \boldsymbol{\lambda}, \mathbf{s}^{+}, \mathbf{s}^{-}}\left(\boldsymbol{\theta}+\varepsilon \mathbf{J} \cdot \mathbf{s}^{+}-\varepsilon \mathbf{J} \cdot \mathbf{s}^{-}\right) \\
\boldsymbol{\theta} \cdot \mathbf{y}_{k}-\mathbf{Y} \cdot \boldsymbol{\lambda}+\mathbf{s}^{+}=\mathbf{0} \\
\mathbf{X} \cdot \boldsymbol{\lambda}-\mathbf{s}^{-}=-\mathbf{x}_{k} \\
\mathbf{J} \boldsymbol{\lambda}=1 \\
\boldsymbol{\lambda}, \mathbf{s}^{+}, \mathbf{s}^{-} \geq \mathbf{0}
\end{gathered}
$$

or in a dual form (which is frequently the one being solved):

$$
\begin{gathered}
\min _{\boldsymbol{v}, v_{k}}\left(\mathbf{v}^{T} \cdot \mathbf{x}_{k}+v_{k}\right) \\
\boldsymbol{\mu}^{\mathrm{T}} \cdot \mathbf{y}_{k}=1 \\
\boldsymbol{\mu}^{\mathrm{T}} \cdot \mathbf{Y}+\mathbf{v}^{T} \cdot \mathbf{X}+u_{k} \cdot \mathbf{J} \geq \mathbf{0} \\
\boldsymbol{\mu}^{\mathrm{T}} \geq \varepsilon \mathbf{J} \\
\mathbf{v}^{\mathrm{T}} \geq \varepsilon \mathbf{J}
\end{gathered}
$$

where $\mathbf{X}-$ is an input matrix $(N x M), \mathbf{Y}$ - output matrix $(N x S), \mathbf{x}_{\mathrm{k}}-$ vector of inputs for $k$-th DMU $(1 \times M), \mathbf{y}_{\mathrm{k}}$ - vector of outputs for $k$-th DMU $(1 \times S), \lambda$ - vector of liner combination coefficients, $\mathbf{s}^{+}, \mathbf{s}^{-}$- vectors of slacks and surpluses, $\boldsymbol{\mu}$ - vector of outputs weights (1 x S), $\mathbf{v}-$ vector of inputs weights $(1 \times M), \theta$ - efficiency coefficient of $k$-th DMU, $\mathbf{J}-$ vector of ones, $\varepsilon$ - infinitesimal value for forestalling weights to be equal to zero.

For each DMU the model generates an efficiency coefficient $\theta$, vector of slacks $\mathbf{s}^{-}$and surpluses $\mathbf{s}^{+}$as well as information on returns to scales (constant, increasing or decreasing). For inefficient units the formula for achieving effectiveness (ceteris paribus) is as follows:

$$
\left(\mathbf{x}_{k}-\mathbf{s}^{-} ; \theta \cdot \mathbf{y}_{k}+\mathbf{s}^{+}\right)
$$

While DEA was created for the problem of classical production, this concept has been extended over the years. Firstly, regions are not "factories", and yet they use resources as effectively and efficiently as possible in order to obtain goals defined by law, social policy, and public expectations. They are governed by elected representatives, who are chosen by the people and for the people. As such they can be treated as a homogenous object and compared by DEA methods and used to establish a spatial efficiency frontier. (Galinienè, Dzemydaite 
2012, pp. 390-399) Secondly, the DEA approach has been used with much success for many topics which are not strictly productive, like health care, public safety, and logistics. (See Suzuki, Nijkamp 2011; Żółtaszek 2014a; Żółtaszek 2014b; Galinienė, Dzemydaitė 2012) It should be mentioned that the DEA model makes it possible to measure relative effectiveness, so values of the efficiency coefficient cannot be compared over time and each year's results should be treated as static.

Since innovation is not an actual production, but a creative process, it should not be treated as fixed and repetitive over time and space. Therefore, out of the available DEA models, a BCC (output oriented) approach with variable returns to scale is introduced. It is assumed that inputs are not utilized in the same way, so in some cases an increase in resources may cause a smaller and in others a larger change of effects in a DMU.

While the DEA methodology was primarily introduced to examine the efficiency, effectiveness, or productivity of companies, it has been gaining popularity among regionalists as well. In general, regions are treated as factories, which operate with limited resources and aim to maximize some tangible effects. Nowadays this approach is used for analysis and comparison of efficiency as well as to detect spatial patterns. Wang and Feng (2015) used DEA methods to research the productivity and economic growth in Chinese regions by analysing three components: input inefficiency, economic output inefficiency, and environmental inefficiency. Dzemydaite and Galinienè used the DEA approach to analyse regional inequalities in planning infrastructure and human capital development (Galinienè, Dzemydaitè 2012, Dzemydaitè, Galinienè, 2013). Athanassopoulos (1996) analysed the social and economic disadvantages of European regions, where "(..) a region will be comparatively disadvantaged if there is another region or combination of regions with a similar or worse socio-demographic profile that deliver(s) higher levels of social and economic value." (Athanassopoulos, 1996, p.442) In most of the available papers, DEA is used on regional data to establish spatial patterns. However, lately DEA analyses are being paired with other methods in order to better pinpoint the spatial regularities. Lao and Liu (2009) combined GIS (Geographic Information Systems) and the DEA method to assess: firstly, the demographic profiles (using GIS), and then the efficiency (DEA) of each bus line in California (Monterey-Salinas Transit). Kapfer, Kantelhardt, Eckstein, and Hübner (2013) also used both GIS and DEA to measure the performance of agricultural land plots in terms of economy and production. Moreover, the authors assumed that DEA results do not take into account environmental and spatial aspects. Therefore, in the second stage of research the efficiency coefficient was modelled using a Tobit model to explain the differences in the 
productivity in land plots in the region Rhön in northern Bavaria, Germany. Schaffer, Simar, and Rauland similarly started with a DEA approach and then modelled the calculated efficiency with geo-additive regression incorporating the spatial weight matrix $\mathbf{W}$. On the other hand, Maté-Sánchez-Val and Madrid-Guijarro (2011) modified the original data by incorporating the spatial effect by weighting inputs and outputs with the $\mathbf{W}$ matrix. Afterward they used a fitted DEA model to solve the optimization problem with spatial interactions.

Combining DEA with ESDA techniques is a relatively new approach to the efficiency analysis of regions. Results of DEA models (efficiency coefficients) are tested for spatial autocorrelation (local and global) in order to verify spatial patterns and clusters of efficiency/productivity. Angeriz, Mccombie, and Roberts, (2006) used this combined methodology to assess manufacturing productivity in 68 European NUTS 1 regions. Similarly, Mokaddem (2015) used DEA analysis and spatial autocorrelation, as well as the spatial econometric model, for pinpointing spatial patterns and dependencies of economic development across 252 Tunisian delegations. This novel approach is also utilized in our paper. While DEA analysis is the focal point of regional innovation assessment, the results for NUTS 2 are afterwards tested for global and local autocorrelation of their efficiency.

In order to verify if there is any spatial autocorrelation of innovation efficiency, local and global Moran's $I$ statistics are used. The local Moran's $I_{i}$ statistic shows whether the $i$-th location is surrounded by locations with similar (positive spatial autocorrelation) or significantly different values (negative spatial autocorrelation). (Moran, 1947; Cliff and Ord, 1981) The local Moran's $I_{i}$ statistic is the base for Local Indicators of Spatial Association LISA. The local Moran's I statistic takes the following form:

$$
I_{i}=\frac{\left(x_{i}-\overline{\boldsymbol{x}}\right)}{\frac{1}{N} \sum_{j=1}^{N}\left(x_{j}-\overline{\boldsymbol{x}}\right)^{2}} \sum_{j=1}^{N} w_{i j}\left(x_{j}-\overline{\boldsymbol{x}}\right)
$$

with $x_{i}$ representing the variable in question, $\overline{\boldsymbol{x}}$ its mean. Symbol $w_{i j}$ represents an element of the W - spatial weight matrix. The global Moran's $I$ measures general regional similarity for all regions as a mean of local Moran's $I_{i}$ statistics. The global Moran's $I$ statistic can be presented as follows:

$$
I=\frac{\sum_{i=1}^{N} \sum_{j=1}^{N} w_{i j}\left(x_{i}-\bar{x}\right)\left(x_{j}-\bar{x}\right)}{\frac{1}{N} \sum_{i=1}^{N}\left(x_{i}-\bar{x}\right)^{2}}
$$

We assume a positive spatial autocorrelation if: $I>-\frac{1}{N-1}$ and negative spatial autocorrelation otherwise.The spatial analysis is based on the contiguity spatial weight matrix (Anselin, 1988). 


\section{Data}

In order to measure the efficiency of innovations of European regions using the DEA approach, two inputs and two outputs have been introduced. It is assumed that the "innovation factories", defined as European countries or EU provinces (defined as NUTS 2 regions) use:

- highly qualified human capital, measured by employment in technology and knowledge-intensive sectors per million of the economically active persons (population);

- financial resources defined by total intramural research and development (R\&D) expenditure in Purchasing Power Standard (PPS) per economically active person (population) at constant 2010 prices (Euro PPS).

The "products" of innovations are defined as:

- patents, measured as the number of patent applications to the European Patent Office (EPO) by priority year per million economically active persons (population);

- Gross domestic product (GDP) in Purchasing Power Standard (PPS) per economically active persons (population) at constant 2010 prices (Euro PPS) - henceforth denoted as GDP per capita.

Original Eurostat variables were transformed to allow for regional comparisons, using information on the total population, fraction of economically active population, expenditure price index 2005 - 2010, and a GDP fixed base price index. The Eurostat database made it possible to include all 28 member states (Austria, Belgium, Bulgaria, Croatia, Cyprus, Czech Rep., Denmark, Estonia, Finland, France, Germany, Greece, Hungary, Ireland, Italy, Latvia, Lithuania, Luxemburg, Malta, Netherlands, Poland, Portugal, Romania, Slovakia, Slovenia, Spain, Sweden, and the UK) for the years 2000 to 2014. Some missing data had to be extrapolated using the assumption of constant average change rate. The basic statistics on inputs and outputs for the 28 European states and NUTS 2 regions are presented in Table 1 and Table 2. 
Table. 1 Basic statistics on inputs and outputs for the 28 European states in years 2000 and 2014

\begin{tabular}{|c|c|r|r|r|r|}
\hline Year & Variable & $\begin{array}{c}\text { R\&D } \\
\text { expenditure in } \\
\text { PPS per } \\
\text { economically } \\
\text { active person at } \\
\text { constant 2010 } \\
\text { prices (€ PPS) }\end{array}$ & $\begin{array}{c}\text { Employment in } \\
\text { technology and } \\
\text { knowledge- } \\
\text { intensive } \\
\text { sectors per } \\
\text { million } \\
\text { economically } \\
\text { active persons }\end{array}$ & $\begin{array}{c}\text { Number of } \\
\text { patent } \\
\text { applications to } \\
\text { the EPO per } \\
\text { million } \\
\text { economically } \\
\text { active persons }\end{array}$ & $\begin{array}{c}\text { GDP PPS per } \\
\text { economically } \\
\text { active person at } \\
\text { constant 2010 } \\
\text { prices (€ PPS) }\end{array}$ \\
\hline \multirow{7}{*}{2000} & Statistic & 671.50 & 904.69 & 160.03 & 50.60 \\
\cline { 2 - 7 } & average & 402.80 & 915.47 & 37.69 & 51.86 \\
\cline { 2 - 7 } & median & $94.05 \%$ & $5.32 \%$ & $121.18 \%$ & $48.75 \%$ \\
\cline { 2 - 7 } & min & 54.40 & 809.21 & 0.52 & 19.39 \\
\hline \multirow{5}{*}{2014} & max & 2130.99 & 977.32 & 558.74 & 148.94 \\
\cline { 2 - 7 } & median & 904.02 & 893.16 & 180.96 & 52.51 \\
\cline { 2 - 7 } & Vs & 675.10 & 910.55 & 69.99 & 48.19 \\
\cline { 2 - 7 } & min & $70.31 \%$ & $5.96 \%$ & $114.72 \%$ & $40.77 \%$ \\
\cline { 2 - 7 } & max & 116.25 & 733.38 & 7.69 & 25.40 \\
\hline
\end{tabular}

Source: own computations, based on Eurostat Database. (Vs - variation coefficient based on standard deviation)

In the year 2000, on average each EU 28 state spent $€ 671.50$ (per economically active person) on $R \& D$, however the median indicates that half of the countries allocated no more than $€ 402.80$. This suggests that the distribution of R\&D expenses are skewed. The high relative standard deviation (94\%) and minimal value ( $€ 54$ in Romania) being over 40 times smaller than the maximum value ( $€ 2130$ in Sweden) confirm a large dispersion. Over time the dispersion in R\&D expenses declined (in 2014 the variation coefficient was $70 \%$, and the relation of maximal to minimal value, for Sweden and Romania respectfully, was smaller than 20).

Employment in technology and knowledge-intensive sectors was very evenly distributed over the 28 member states and stable over time (2000-2014). On average, there are around 900 employees (per million) in this sector, measured by the mean and median, with very little dispersion (variation coefficient of 5-6\%).

The number of patent applications to the EPO increased over time and is strongly diverse across countries. While the average number of patents increased from 160 in 2000 to 180 in 2014, the median of 38 in 2000 and 70 in 2014 shows a large asymmetry of the distribution. Additionally, the relative standard deviation confirms considerable dispersion ( $121 \%$ in $2000,115 \%$ in 2015$)$. In the year 2000 the minimal number for patents $(0.52$ (per million persons) in Romania) is over 1100 times smaller than the maximum number for 
Germany. In 2014 this ratio was much smaller, around 90, with Croatia (7.7) at the bottom and Finland (692) at the top of the list.

GDP per capita in general has been stable over time and characterised by a symmetric distribution with moderate dispersion. On average (by mean and median) each country generates around $€ 50$ per capita, with dispersion less than $50 \%$. The highest value can be observed for Luxemburg, while the lowest was for Romania (2000) and Bulgaria (2014).

The regional analysis was performed for 261 NUTS 2 regions, and for the EU 28 (with the exception of Croatia, due to the unavailability of data). The problem of missing data narrowed the research period to the year 2012, for which the most recent data are available.

Tab. 2 Basic statistics of inputs and outputs for NUTS 2 regions, 2012

\begin{tabular}{|c|c|c|c|c|c|}
\hline Year & $\begin{array}{c}1 \\
\text { Statistic }\end{array}$ & $\begin{array}{c}\text { R\&D } \\
\text { expenditure in } \\
\text { PPS per } \\
\text { economically } \\
\text { active person at } \\
\text { constant } 2010 \\
\text { prices ( } € \text { PPS) }\end{array}$ & $\begin{array}{l}\text { Employment in } \\
\text { technology and } \\
\text { knowledge- } \\
\text { intensive } \\
\text { sectors per } \\
\text { million } \\
\text { economically } \\
\text { active persons }\end{array}$ & $\begin{array}{l}\text { Number of } \\
\text { patent } \\
\text { applications to } \\
\text { the EPO per } \\
\text { million } \\
\text { economically } \\
\text { active persons }\end{array}$ & $\begin{array}{l}\text { GDP PPS per } \\
\text { economically } \\
\text { active person at } \\
\text { constant } 2010 \\
\text { prices ( } € \text { PPS) }\end{array}$ \\
\hline \multirow{5}{*}{2012} & average & 788.11 & 904.94 & 171.02 & 44.01 \\
\hline & median & 547.61 & 920.02 & 108.82 & 47.70 \\
\hline & Vs & $104.92 \%$ & $7.51 \%$ & $115.94 \%$ & $51.13 \%$ \\
\hline & $\min$ & 11.27 & 649.18 & $7 \cdot 10^{-6}$ & 4.10 \\
\hline & $\max$ & 6697.77 & 1106.72 & 1124.14 & 177.37 \\
\hline
\end{tabular}

Source: own computations, based on Eurostat Database. (Vs - variation coefficient based on standard deviation)

In analysing the distribution of four input and output variables for NUTS 2 regions, it can be observed that average values (means and medians) are similar to the country-level distribution. The skewness of $R \& D$ expenditures is stronger for countries, but weaker for the number of patents. Also, for NUTS 2 regions all variables show more dispersion at the higher level of aggregation, which is no surprise as micro-data are typically less homogenous.

\section{Results}

In order to analyse the regional effectiveness of innovations, a DEA analysis was performed. The BCC output-oriented model, with 2 inputs and 2 outputs, has been used for the EU28 during the years 2000-2014 (outcomes for exterior years are presented below). The analogical approach has been incorporated for NUTS 2 regions for year 2012. Complete results for the EU28 for the years 2000, 2007, 2012, and 2014, as well as the EU NUTS 2 
regions for 2012 are available in the Appendix. All calculations were carried out in STATA MP and visualisations were created in QGIS.

\subsection{Results for the 28 EU countries in 2000-2014}

Research into the regional effectiveness of innovations of EU member states divides the countries into two categories: efficient (with efficiency coefficient $\theta$ equal 100\%), and inefficient (with $\theta>100 \%$ ). (see Fig.1 and Appendixes 1-4). The analysis shows that for most of the researched period, out of the 28 states around 10 were fully efficient, i.e. they fully utilized their inputs to "produce" outputs of innovations. The rest of the countries could have performed better by increasing their outputs and decreasing some inputs, according to formula 8 (a projection to efficiency frontier or "recipe for efficiency"). For instance, the Czech Republic in the year 2014 has an efficiency coefficient $\theta$ equal $171.7 \%$. Therefore, with its level of inputs the state could have produced $171.7 \%$ of the actual outputs (i.e. increased both outputs by $71.7 \%$ ). Moreover, one of the outputs (number of patents) could have been additionally increased by 16.79 units (as the vector of surpluses $\mathbf{s}^{+}$indicates) and one of the inputs (employment in technology and knowledge-intensive sectors) should have been lower by 58.11 units (as the vector of slacks $\mathbf{s}^{-}$indicates). Altogether the optimal values of Czech's variables should be as follows (see Appendix 4 and formula 8):

$$
\begin{gathered}
\left(\mathbf{x}_{\text {Czech }}-\mathbf{s}^{-} ; \theta \cdot \mathbf{y}_{\text {Czech }}+\mathbf{s}^{+}\right)= \\
=\left(\left[\begin{array}{ll}
835.57 & 936.98
\end{array}\right]-\left[\begin{array}{ll}
0 & 58.11
\end{array}\right] ; 171.7 \% \cdot\left[\begin{array}{ll}
50.21 & 48.19
\end{array}\right]+\left[\begin{array}{ll}
16.77 & 0
\end{array}\right]\right)= \\
=\left(\left[\begin{array}{ll}
835.57 & 878.87
\end{array}\right] ;\left[\begin{array}{ll}
102.98 & 48.19
\end{array}\right)\right.
\end{gathered}
$$

where $\mathbf{x}_{\text {Czech }}=\left[\begin{array}{ll}835.57 & 936.98\end{array}\right]$ is the vector of the actual (historic) inputs with R\&D expenditure as $x_{1}$ and Employment in technology and knowledge-intensive sectors as $x_{2}$; and $\mathbf{y}_{\text {Czech }}=\left[\begin{array}{ll}50.21 & 48.19\end{array}\right]$ is the vector of actual (historic) outputs with number of patent applications as $y_{1}$ and GDP per capita as $y_{2}$. 


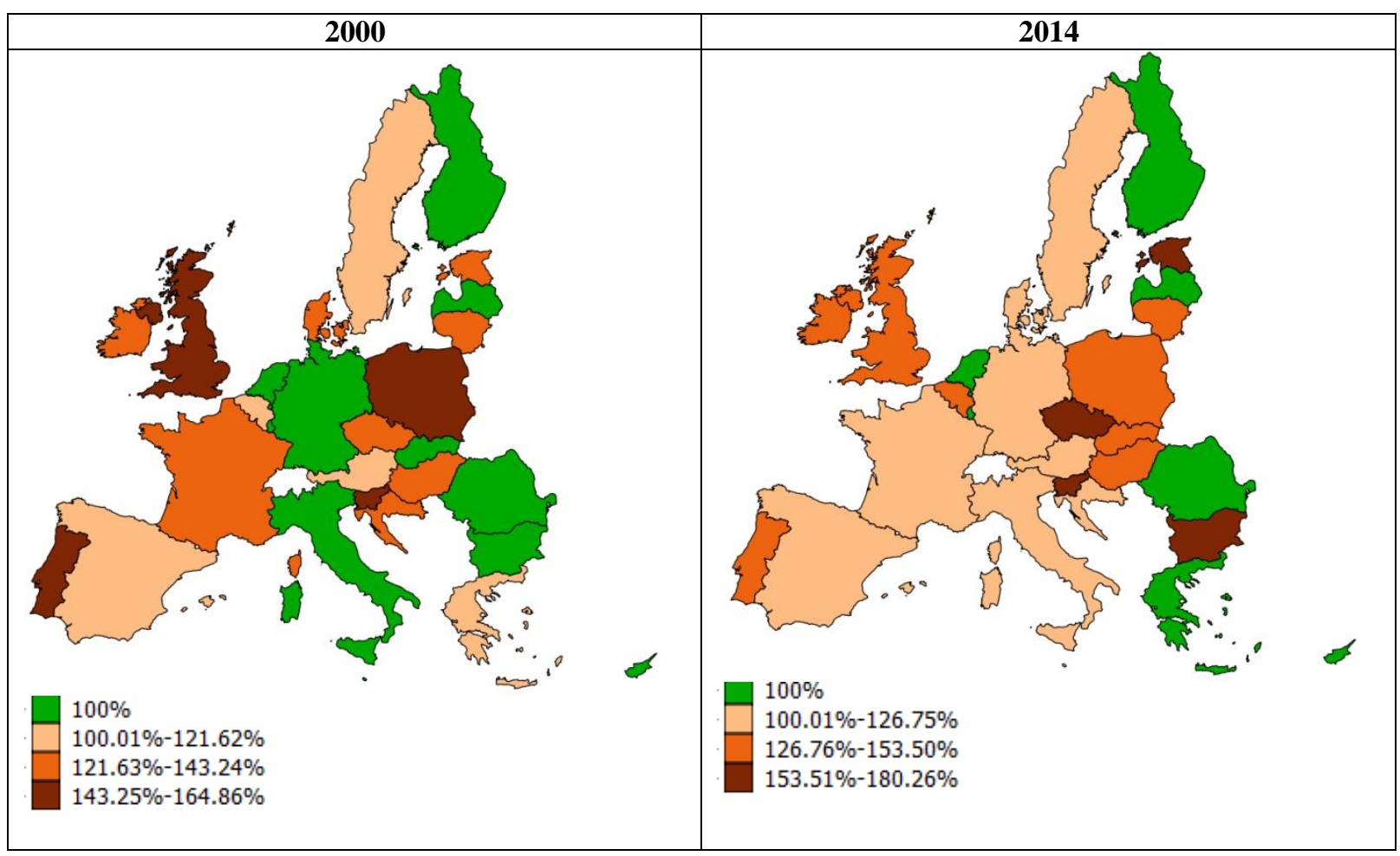

Figure 1. Efficiency coefficient [\%] by country in the years 2000 and 2014

Source: own work in QGIS, STATA MP DEA BCC output-oriented model results.

Figure 1 illustrates the efficiency coefficients of the EU28 countries in years 2000 and 2014. Over this period the number of fully efficient countries, i.e. that achieved their innovation potential, decreased from 10-11 (up to 2012) to 7 (in 2014). In 2000 the leaders of innovation were: Bulgaria, Cyprus, Finland, Italy, Latvia, Luxemburg, Malta, the Netherlands, Romania, and Slovakia. In 2014 the most efficient states were: Cyprus, Finland, Greece, Latvia, Luxemburg, the Netherlands, and Romania. Overall, only Cyprus, Luxemburg, and the Netherlands continued to be efficiency leaders of EU throughout the entire period (see Figure 1 and Appendixes 1-4). In the meantime, the level of inefficiency, as measured by the efficiency coefficient, kept growing. The worst performing countries underachieved their goals (patents and GDP per capita) by 60-122\%. The lowest performance (by top three values of the efficiency coefficient) can be observed for Estonia since 2007, the Czech Republic since 2012, and, on and off Slovenia, Poland, and Portugal. It is also interesting that the number of countries with extreme values (i.e. both fully efficient and very inefficient) declined over time. This suggests either that the efficiency of innovations regress to the centre values, or alternatively a convergence thereof across EU states.

Taking into consideration the variable returns to scale of innovation efficiency, it is clear that the pace of intellectual progress is decreasing (see Figure 2 and Appendixes 1-4). In year 2000, 18 out of 28 countries had increasing returns to scale, which enabled a more than 
proportional growth of outputs for each $1 \%$ increase of inputs. Over time, the number of increasing returns to scale has outpaced by decreasing returns (13 states in 2014). Moreover, a pattern has emerged where the countries of Western Europe still maintain increasing returns, while the Central-Eastern countries have decreasing or constant effects. For states with decreasing returns to scale, the outcomes of innovations are more slow (or less than proportional) than the inputs. Thus growing expenses and employment in the R\&D sector do not translate into a higher efficiency of innovations.

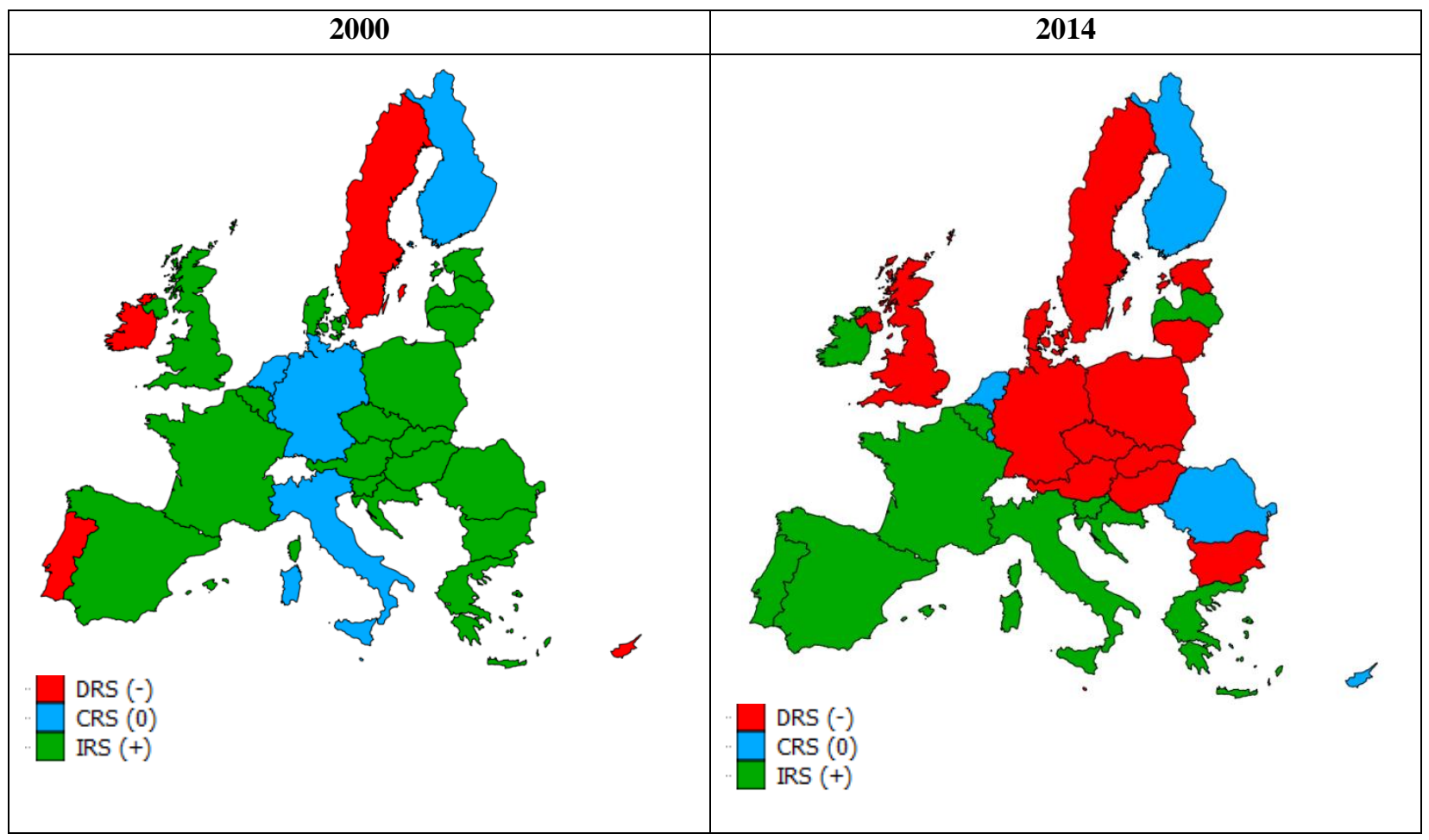

Figure 2. returns to scale (DRS- decreasing, CRS-constant, INS-increasing) by country in years 2000 and 2014

Source: own work in QGIS, STATA MP DEA BCC output-oriented model results.

\subsection{Results for EU NUTS 2 regions in 2012}

The next step of the analysis is the application of an analogical approach for EU NUTS 2 regions for 2012 with NUTS 0 as benchmarks. It can be observed that the regional distribution of innovation efficiency is much different. (see Figure 3 and Appendixes $3 \& 5$ ) 


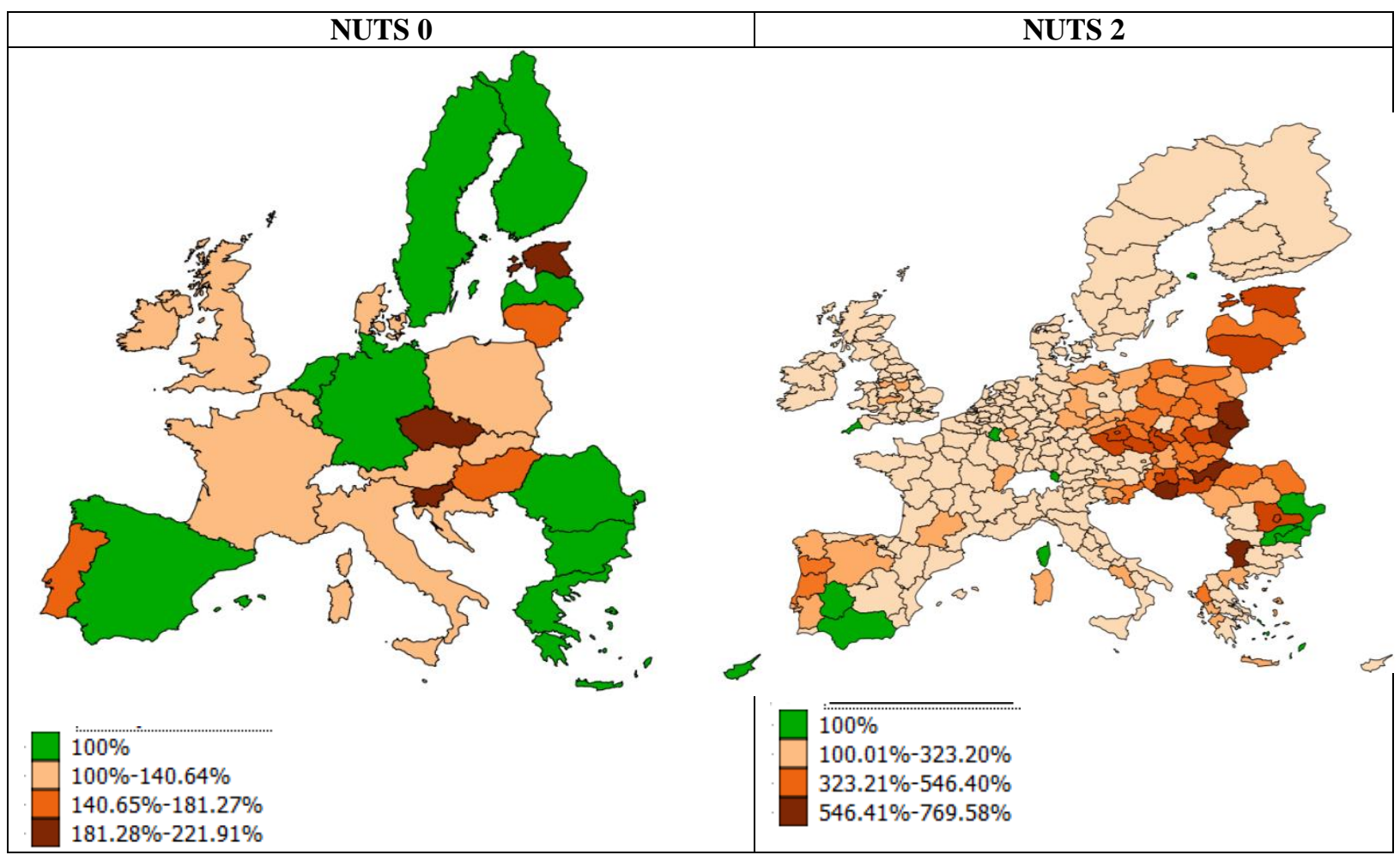

Figure 3. Efficiency coefficient [\%] by EU NUTS 0 and NUTS 2 regions in year 2012

Source: own work in QGIS, STATA MP DEA BCC output-oriented model results.

In 2012, 11 of 28 countries were efficient, while the worst performing region had an efficiency coefficient of $222 \%$ (Estonia). Out of 261 provinces only 12 were fully efficient in their innovations: Vorarlberg (Austria), Luxembourg (Belgium), Severen tsentralen (Bulgaria), Severoiztochen (Bulgaria), South Aegean (Greece), Extremadura (Spain), Andalusia (Spain), Åland (Finland), Corsica (France), Sud-Est (Romenia), Inner London (UK), and Cornwall and the Isles of Scilly (UK). The maximum inefficiency can be observed at $769.6 \%$, which means that the number of patents and GDP per active person could have been 7.5 times higher with given inputs, with the worst performing regions being: Yugozapaden with Sofia (Bulgaria), Southern Transdanubia (Hungary), Northern Great Plain (Hungary), Lubelskie and Podkarpackie (Poland). The diversity of innovations (measured by efficiency) is much higher for NUTS 2 regions than for countries. Only $4.5 \%$ of provinces are fully realizing their innovation potential. (see Figure 3 and Appendixes $3 \& 5$ ) 


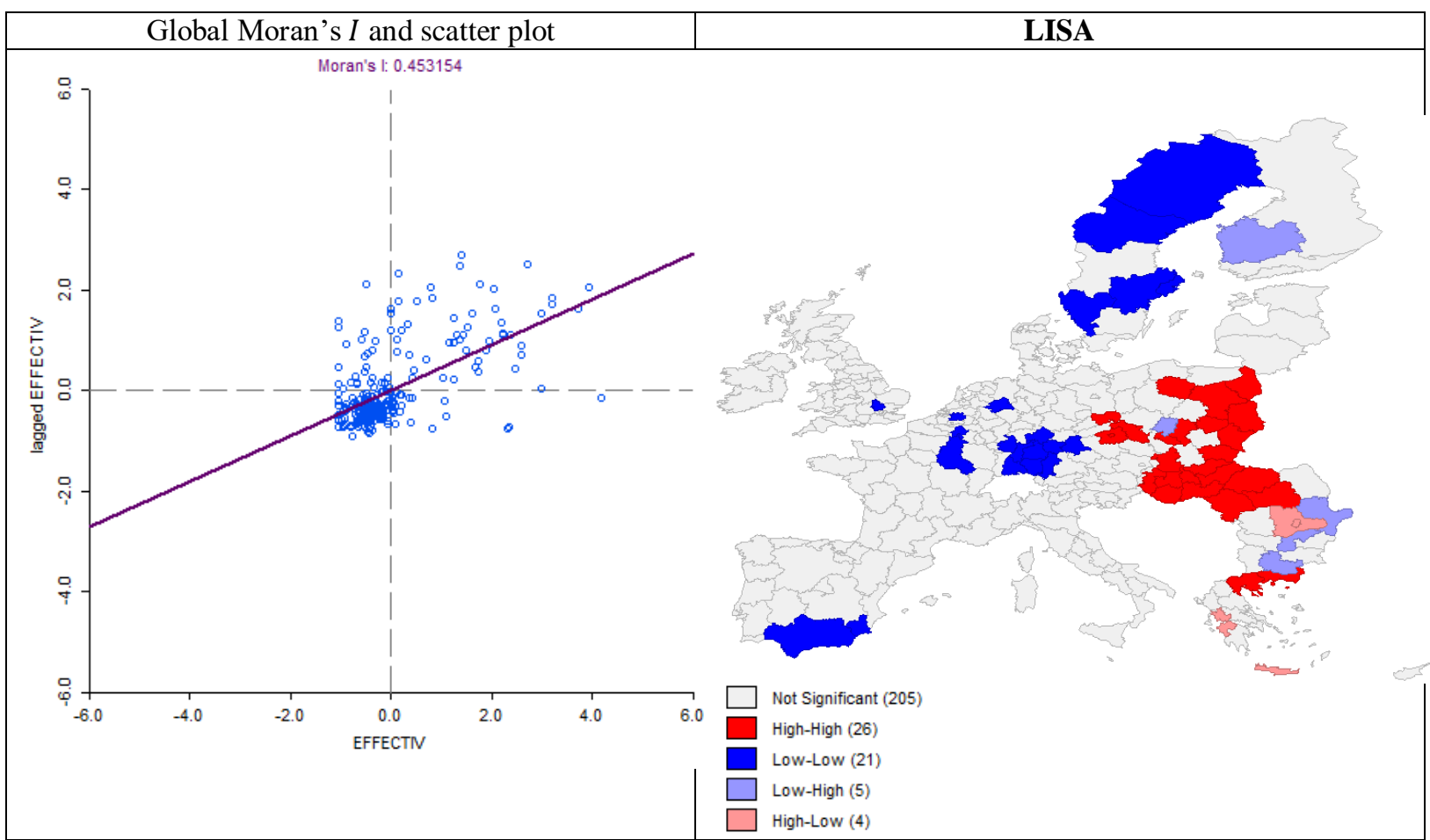

Figure 4. Spatial autocorrelation analysis of efficiency coefficient for innovations by NUTS 2 regions for the year 2012

Source: own work in GeoDa, based on STATA MP results for DEA BCC output-oriented model.

Figure 4 presents the results of the autocorrelation analysis. The spatial autocorrelation of innovation effectiveness for NUTS2 regions in year 2012 is high, with Moran's $I=0.45$. This means that on average, innovation effectiveness in one region is similar to the effectiveness in the bordering regions. This is also reflected by the local indicator of spatial autocorrelation. Figure 4 (on the right) presents the LISA cluster map of effectiveness. We can observe here 26 hot-spots and 21 cold-spots. The former are regions with a high efficiency coefficient, which indicates a poor performance in innovations, which coincides with similar high levels of coefficient $\theta$ for their neighbours. These high-high clusters are located mainly in Central and Eastern Europe, namely in: Germany, the Czech Republic, Poland, Slovakia, Hungary, Romania, and Greece. The cold-spots, or low-low clusters, are regions with a low efficiency coefficient, hence fully efficient or close to full efficiency, and also surrounded by similar regions. These low-low clusters are located mainly in Western Europe, including regions in: Sweden, Germany, Netherlands, Belgium, Luxemburg, France, UK (around London), and Spain. Therefore, the efficiency of innovations has a statistically significant spatial pattern. In general, low efficiency (i.e. a high efficiency coefficient) is more typical for Central and Eastern Europe, while high efficiency (represented by a lower efficiency coefficient) is located primarily in Western Europe. 
Figure 5 presents the returns to scale of efficiency of innovations by province. In terms of countries there are 16 out of 28 (almost 60\%) with increasing returns to scale, mainly in Western Europe, the Balkans, and the Baltic States (decreasing and content effects in six countries). Among the 11 efficient states, six have constant returns to scale, four increasing, and one decreasing. In the analysis for NUTS 2 regions almost 70\% of regions (180 of 261) have decreasing returns to scale, $28 \%$ have increasing returns, and only $3 \%$ constant. However, this $3 \%$ (seven regions) have efficiency of $100 \%$, while the remaining five efficient regions have increasing returns to scale. Overall constant returns to scale are typical only for efficient regions (both for NUTS 0 and NUTS 2). Also, some leaders of innovations have increasing economies of scale. In the NUTS 2 analysis almost $70 \%$ of provinces have decreasing returns to scale, which indicates a slower than proportional increase in innovations compared to the increase of inputs. In Spain, Finland, Latvia, Slovakia, Hungary, and Greece increasing returns to scale characterise all or most of the countries' provinces, which result in similar returns as the NUTS 0 level. In Germany, the UK, the Czech Republic, Austria, Netherlands, Belgium, and Luxemburg, almost all provinces have decreasing returns to scale, therefore their total result for NUTS 0 is the same. However, France, Belgium, Slovenia and Italy, despite having decreasing returns at the NUTS 2 level, altogether have increasing returns to scale at the NUTS 0 level.

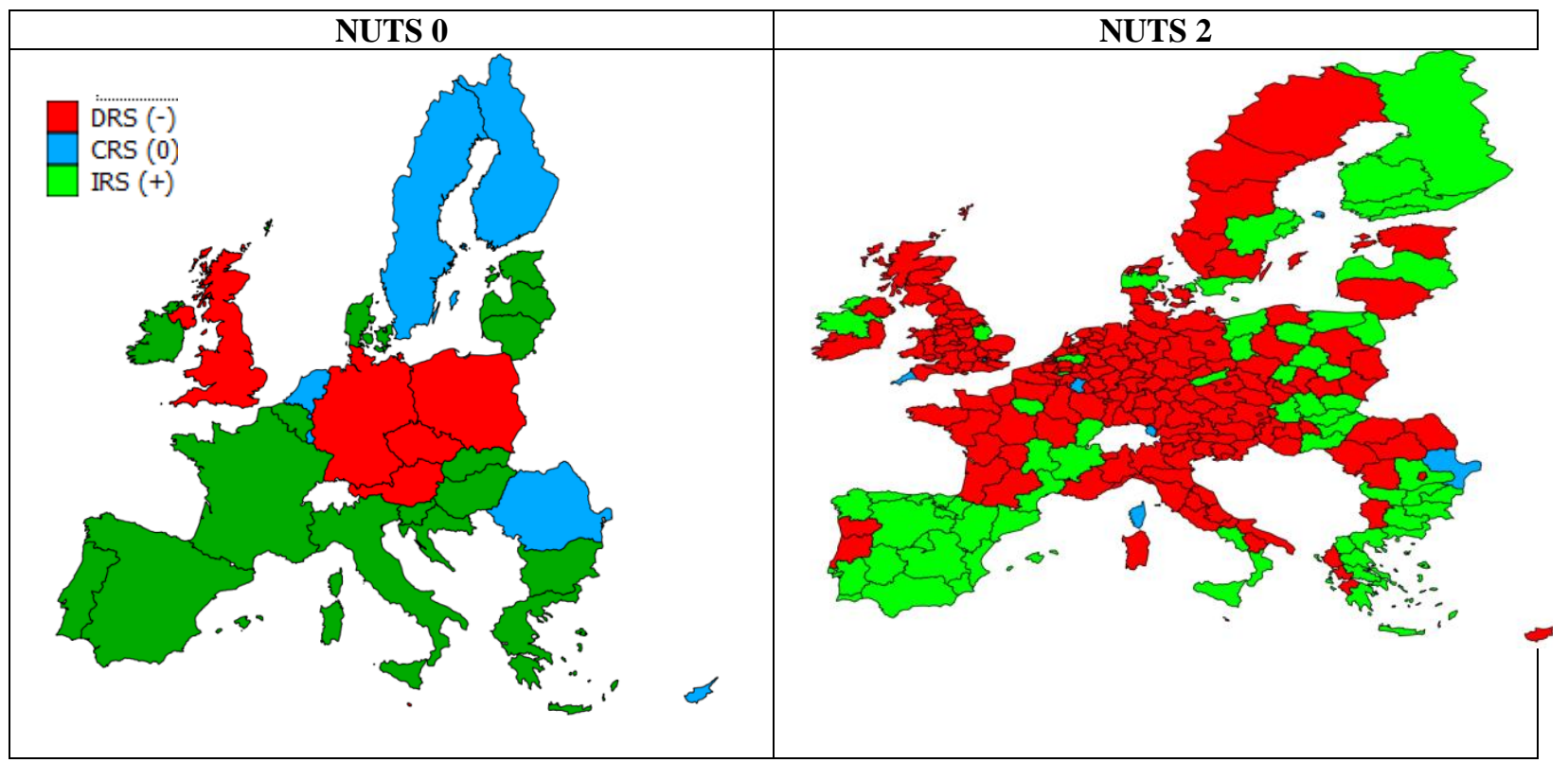

Figure 5. Returns to scale (DRS- decreasing, CRS-constant, INS-increasing) by NUTS 0 and NUTS 2 regions in year 2012

Source: own work in QGIS, STATA MP DEA BCC output-oriented model results,. 


\section{Conclusions}

In this paper we employed a strictly quantitative analysis to the problem of regional innovation potential. The DEA model made it possible to measure the effectiveness of innovations in the EU28 countries and in 261 regions over the long run. Unlike the more typical approaches, the DEA model does not assess the level of innovations, but the percentage of realized potential of innovations. Therefore it is possible that both high innovative regions (connecting high inputs with high outputs, e.g. Germany, Scandinavia) and low innovative ones (with low inputs and low outputs, e.g. the Balkans) fully utilize their potential and perform effectively. On the other hand, if high/low inputs do not correspond with a proportional level of outputs, a region is underperforming and wasting its innovative potential. The DEA results are relative (always referring to the set of regions included in the research) and static (which diminishes the possibility of analysing effectiveness over time).

The performed efficiency analysis indicates that the number of regions which fully utilize their innovative potential is decreasing over time. In particular the research for NUTS 2 provinces shows less than $5 \%$ of efficient regions, scattered across the EU, while for countries $25 \%-40 \%$ perform exemplary. However, expanding the DEA analysis by spatial statistics resulted in pinpointing the spatial patterns in the distribution of innovation efficiency (for NUTS 2 regions, as the state level has too few objects). Central and Eastern Europe (including parts of Germany, the Czech Republic, Poland, Slovakia, Hungary, Romania, and Greece) contain a considerable cluster of high efficiency. These regions realize their innovative potential to a very high degree (but not fully). Conversely, low innovative clusters are typical for Western Europe (notably parts of: Sweden, Germany, the Netherlands, Belgium, Luxemburg, France, the UK, and Spain), where regions underachieve their innovative potential. These results are largely contradictory with the European Commission's Regional Innovation Scoreboard, which pinpoints NUTS 2 regions in Scandinavia, Germany, France and UK as innovation leaders or strong innovators, while Central and Eastern Europe is characterised as having moderate and modest innovators. (European Innovation Scoreboard, 2016) These dissimilarities may suggest that it is easier to highly utilize the innovative potential for regions if there is a lower level of innovations.

Comparison of the regional and country efficiency indicates a vast effectiveness gap for NUTS 2 regions, compared to a much smaller diversity for countries. The dispersion of ineffectiveness is increasing over time. Moreover, the main source of inefficiency for states 
are too few patents to EPO (output), but for NUTS 2 the sources of inefficiency are too high employment in technology and knowledge-intensive sectors as well as R\&D expenses (inputs).

The DEA analysis also included returns to scale, which indirectly incorporates the qualitative aspect of innovations. This aspect shows the expected effect of increasing inputs on innovations (R\&D expenses and human capital). Over the time (i.e. from 2000 to 2014) the dynamics of returns to scale slowly switched from increasing to decreasing. Most countries and regions achieve, by increasing their inputs, less than proportional increases of outputs. Moreover, regional and state returns to scale overlap for the majority of countries. These results suggest that returns to scale have a country-specific element. The distribution of returns to scale corresponds neither with the level of innovations (European Innovation Scoreboard, 2016) nor the efficiency of innovations (DEA results). This strengthens the possibility that specific factors are involved.

In conclusion, the DEA analysis made it possible to indicate leaders and followers (at the NUTS 0 and NUTS 2 level) in innovations, as well as the main sources of lost efficiency. However it does not take into account any quality-based aspects, like creativity of the innovation process, the structure of $\mathrm{R} \& \mathrm{D}$ organizations (companies, research facilities, universities), and the types of innovations. Therefore, it would be beneficial to conduct complementary research, including social, educational, and legal factors, to cross-reference the results and conclusions.

\section{Literature}

Athanassopoulos, A.D. (1996) Assessing the comparative spatial disadvantage (CSD) of regions in the European Union using non-radial data envelopment analysis methods, European Journal of Operational Research 94, 439-452

Angeriz, A., Mccombie, J., Roberts, M. (2006) Productivity, efficiency and technological change in European union regional manufacturing: a data envelopment analysis approach, The Manchester School Vol 74 No. 4 Special Issue 2006 1463-6786 500-525

Anselin L., (1988), Spatial Econometrics: Methods and Models, Kluwer Academic Publications, Dordrecht.

Charnes, A., Cooper, W.,Rhodes, A. (1978) Measuring the efficiency of decision making units [in:] European Journal of Operations Research 
Charnes, A., Cooper, W.,Golany, W., Seinford, B. (1997) Data Envelopement Anaysis. Theory, Methodology, and Applications, Kluwer Academc Piblishers

Cliff A., Ord J. K., (1981), Spatial Processes: Models and Applications, Pion, London.

Dzemydaitè, G., Galinienè, B. (2013) Evaluation of regional efficiency disparities by efficient frontier analysis, Ekonomika Vol. 92(4), 21-36

Galinienė, B., Dzemydaitė. G. (2012) Spatial Data Envelopment Analysis Method for the Evaluation of Regional Infrastructure Disparities, Social Technologies 2012, 2(2), pp. 390-403.

Gospodarowicz, M. (2000) Procedury analizy i oceny banków. [in] Materiały i studia NBP zeszyt nr 103, Narodowy Bank Polski Departament Analiz i Badań, Warszawa, pp. 48-51; Golany, B., Roll, Y. (1989) An application procedure for DEA. OMEGA Heft Vol. 17, pp. 240-247.

Gospodarowicz, A. (2002) Analiza i ocena banków oraz ich oddziałów, Wydawnictwo Akademii Ekonomicznej im. Oskara Langego, Wrocław,

Moran P., (1950) Notes on Continuous Stochastic Phenomena, Biometrika, 37, 17-23.

Kapfer M., Kantelhardt J., Eckstein K., Hübner R. (2013) Environmental and Economic Impact of Agricultural Land Use - a Spatially Explicit DEA Approach, Working paper 2nd AIEAA Conference "Between Crisis and Development: which Role for the Bio-Economy"

Lao, Y., Liu, L (2009) Performance evaluation of bus lines with data envelopment analysis and geographic information systems, Computers, Environment and Urban Systems 33, 247-255

Maté-Sánchez-Val, M. L., Madrid-Guijarro, A. (2011) A spatial efficiency index proposal: an empirical application to SMEs productivity, The Annals of Regional Science - Springer, 47:353-371, DOI 10.1007/s00168-010-0382-8

Mokaddem, L. (2015) Regions` efficiency and spatial disparities in Tunisia, Second International Conference On Advances In Management, Economics And Social Science - MES 2015, ISBN: 978-1-63248-046-0 doi: 10.15224/ 978-1-63248-046-0-131, 207-216

Schaffer, A.; Simar, L., Rauland, J. (2010) Decomposing Regional Effciency, Working Paper Series in Economics, No. 10 OCTOBER 2010

Schaffer, A.;, Simar, L., Rauland, J. (2011) Decomposing Regional Effciency, Journal of Regional Science, Vol. 51, No 5, 2011, 931-947.

Suzuki S., Nijkamp P. (2011), A Stepwise Projection Data Envelopment Analysis for Public Transport Operations in Japan, Tinbergen Institute Discussion Paper, TI 2011-113/3.

Toloo, M., Nalchigar, S. (2009) A new integrated DEA model for finding most BCC-efficient DMU, Applied Mathematical Modelling 33, pp. 597-604

Wang, Z., Feng, C. (2015) Sources of production inefficiency and productivity growth in China: A global data envelopment analysis, Energy Economics 49, 380-389 
Żółtaszek, A. (2014a) Efektywność i Konkurencyjność Systemów Opieki Zdrowotnej Krajów Unii Europejskiej, Przegląd Statystyczny, R. LXI - Zeszyt 1, pp. 79-94

Żóltaszek, A. (2014b) Leaders And Followers In The Effectiveness Of Public Safety Services In European States - A Spatial Frontier Approach, Comparative Economic Research, Volume 17, Number 4, 
Appendix 1. Results of DEA BCC output-oriented model for the EU28 in year 2000

\begin{tabular}{|c|c|c|c|c|c|c|}
\hline \multirow[b]{2}{*}{$\begin{array}{c}\text { DMU: } \\
\text { NUTS } 0\end{array}$} & \multirow[b]{2}{*}{$\begin{array}{c}\text { Efficiency } \\
\text { coefficient } \\
\Theta[\%]\end{array}$} & \multicolumn{2}{|c|}{$\begin{array}{c}\text { Additional inputs reduction } \\
\text { (slacks s-) }\end{array}$} & \multicolumn{2}{|c|}{ 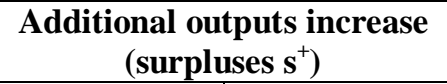 } & \multirow[b]{2}{*}{$\begin{array}{c}\text { returns to } \\
\text { scale: DRS(- } \\
\text { )-decreasing, } \\
\text { CRS(0)- } \\
\text { constant, } \\
\text { IRS(+) } \\
\text { increasing }\end{array}$} \\
\hline & & $\begin{array}{c}\text { R\&D } \\
\text { expenditure } \\
\text { in PPS per } \\
\text { economically } \\
\text { active } \\
\text { person at } \\
\text { constant } \\
2010 \text { prices } \\
(€ \text { PPS) }\end{array}$ & $\begin{array}{c}\text { Employment } \\
\text { in } \\
\text { technology } \\
\text { and } \\
\text { knowledge- } \\
\text { intensive } \\
\text { sectors per } \\
\text { million } \\
\text { economically } \\
\text { active } \\
\text { persons }\end{array}$ & $\begin{array}{c}\text { Number of } \\
\text { patent } \\
\text { applications } \\
\text { to the EPO } \\
\text { per million } \\
\text { economically } \\
\text { active } \\
\text { persons }\end{array}$ & $\begin{array}{c}\text { GDP PPS } \\
\text { per } \\
\text { economically } \\
\text { active } \\
\text { person at } \\
\text { constant } \\
2010 \text { prices } \\
\text { (€ PPS) }\end{array}$ & \\
\hline Austria & $120.7 \%$ & 0 & 0 & 0 & 0 & $\operatorname{IRS}(+)$ \\
\hline Belgium & $120.9 \%$ & 0 & 0 & 0 & 0 & $\operatorname{IRS}(+)$ \\
\hline Bulgaria & $100.0 \%$ & 0 & 0 & 0 & 0 & $\operatorname{IRS}(+)$ \\
\hline Croatia & $136.3 \%$ & 0 & 0 & 9.40691 & 0 & $\operatorname{IRS}(+)$ \\
\hline Cyprus & $100.0 \%$ & N/A & N/A & N/A & N/A & DRS(-) \\
\hline Czech & $123.4 \%$ & 0 & 0 & 54.3346 & 0 & IRS(+) \\
\hline Denmark & $124.6 \%$ & 0 & 0 & 0 & 0 & $\operatorname{IRS}(+)$ \\
\hline Estonia & $134.1 \%$ & 0 & 0 & .947254 & 0 & IRS(+) \\
\hline Finland & $100.0 \%$ & N/A & N/A & N/A & N/A & CRS(0) \\
\hline France & $122.3 \%$ & 0 & 0 & 0 & 0 & $\operatorname{IRS}(+)$ \\
\hline Germany & $100.0 \%$ & N/A & N/A & N/A & N/A & CRS(0) \\
\hline Greece & $100.2 \%$ & 0 & 0 & 31.7506 & 0 & $\operatorname{IRS}(+)$ \\
\hline Hungary & $143.2 \%$ & 0 & 0 & 18.372 & 0 & $\operatorname{IRS}(+)$ \\
\hline Ireland & $125.2 \%$ & 0 & 3.31483 & 0 & 0 & DRS(-) \\
\hline Italy & $100.0 \%$ & 0 & 0 & 0 & 0 & CRS(0) \\
\hline Latvia & $100.0 \%$ & N/A & N/A & N/A & N/A & $\operatorname{IRS}(+)$ \\
\hline Lithuania & $132.9 \%$ & 0 & 0 & 1.75971 & 0 & $\operatorname{IRS}(+)$ \\
\hline Lux & $100.0 \%$ & N/A & N/A & N/A & N/A & CRS(0) \\
\hline Malta & $100.0 \%$ & N/A & N/A & N/A & N/A & CRS(0) \\
\hline Netherl & $100.0 \%$ & N/A & N/A & N/A & N/A & CRS(0) \\
\hline Poland & $153.3 \%$ & 0 & 0 & 7.11879 & 0 & $\operatorname{IRS}(+)$ \\
\hline Portugal & $153.1 \%$ & 0 & 0.517571 & 41.2599 & 0 & DRS(-) \\
\hline Romania & $100.0 \%$ & N/A & N/A & N/A & N/A & $\operatorname{IRS}(+)$ \\
\hline Slovakia & $100.0 \%$ & N/A & N/A & N/A & N/A & $\operatorname{IRS}(+)$ \\
\hline Slovenia & $164.9 \%$ & 0 & 0 & 14.7342 & 0 & IRS(+) \\
\hline Spain & $102.4 \%$ & 0 & 0 & 31.901 & 0 & $\operatorname{IRS}(+)$ \\
\hline Sweden & $107.1 \%$ & 718.723 & 22.4561 & 0 & 0 & DRS(-) \\
\hline UK & $147.1 \%$ & 0 & 0 & 0 & 0 & $\operatorname{IRS}(+)$ \\
\hline
\end{tabular}

Source: own work. (N/A - for DMUs with 100\% efficiency coefficient no additional changes of inputs and/or outputs are offered)

Appendix 2. Results of DEA BCC output-oriented model for the EU28 in year 2007

\begin{tabular}{|c|c|c|c|c|c|c|}
\hline \multirow[b]{2}{*}{$\begin{array}{c}\text { DMU: } \\
\text { NUTS } 0\end{array}$} & \multirow[b]{2}{*}{$\begin{array}{c}\text { Efficiency } \\
\text { coefficient } \\
\Theta[\%]\end{array}$} & \multicolumn{2}{|c|}{$\begin{array}{c}\text { Additional inputs reduction } \\
\text { (slacks s-) }\end{array}$} & \multicolumn{2}{|c|}{$\begin{array}{c}\text { Additional output increase } \\
\left(\text { surpluses } \mathbf{s}^{+}\right)\end{array}$} & \multirow[b]{2}{*}{$\begin{array}{c}\text { returns to } \\
\text { scale: DRS(- } \\
\text { )-decreasing, } \\
\text { CRS }(0)- \\
\text { constant, } \\
\text { IRS(+) } \\
\text { increasing }\end{array}$} \\
\hline & & $\begin{array}{c}\text { R\&D } \\
\text { expenditure } \\
\text { in PPS per } \\
\text { economically } \\
\text { active } \\
\text { person at } \\
\text { constant } \\
2010 \text { prices }\end{array}$ & $\begin{array}{c}\text { Employment } \\
\text { in } \\
\text { technology } \\
\text { and } \\
\text { knowledge- } \\
\text { intensive } \\
\text { sectors per } \\
\text { million } \\
\end{array}$ & $\begin{array}{c}\text { Number of } \\
\text { patent } \\
\text { applications } \\
\text { to the EPO } \\
\text { per million } \\
\text { economically } \\
\text { active } \\
\text { persons }\end{array}$ & $\begin{array}{c}\text { GDP PPS } \\
\text { per } \\
\text { economically } \\
\text { active } \\
\text { person at } \\
\text { constant } \\
2010 \text { prices } \\
(€ \text { PPS }) \\
\end{array}$ & \\
\hline
\end{tabular}




\begin{tabular}{|c|c|c|c|c|c|c|}
\hline & & $(€$ PPS $)$ & $\begin{array}{c}\text { economically } \\
\text { active } \\
\text { persons }\end{array}$ & & & \\
\hline Austria & $121.2 \%$ & 0 & 41.3228 & 0 & 0 & DRS(-) \\
\hline Belgium & $110.9 \%$ & 0 & 0 & 0 & 0 & IRS(+) \\
\hline Bulgaria & $100.0 \%$ & N/A & N/A & N/A & N/A & CRS $(0)$ \\
\hline Croatia & $100.0 \%$ & N/A & N/A & N/A & N/A & $\operatorname{IRS}(+)$ \\
\hline Cyprus & $100.0 \%$ & N/A & N/A & N/A & N/A & CRS(0) \\
\hline Czech & $142.6 \%$ & 0 & 0 & 16.7243 & 0 & DRS(-) \\
\hline Denmark & $120.7 \%$ & 0 & 36.5305 & 0 & 0 & DRS(-) \\
\hline Estonia & $161.0 \%$ & 0 & 0 & 0 & 0 & IRS(+) \\
\hline Finland & $117.5 \%$ & 229.525 & 0 & 0 & 0 & DRS(-) \\
\hline France & $114.5 \%$ & 0 & 0 & 0 & 0 & $\operatorname{IRS}(+)$ \\
\hline Germany & $100.0 \%$ & N/A & N/A & N/A & N/A & CRS(0) \\
\hline Greece & $100.0 \%$ & N/A & N/A & N/A & N/A & CRS(0) \\
\hline Hungary & $153.7 \%$ & 0 & 0 & 0 & 0 & IRS(+) \\
\hline Ireland & $116.3 \%$ & 0 & 0 & 0 & 0 & IRS(+) \\
\hline Italy & $100.0 \%$ & N/A & N/A & N/A & N/A & CRS(0) \\
\hline Latvia & $140.3 \%$ & 0 & 49.0015 & 0 & 0 & IRS(+) \\
\hline Lithuania & $157.2 \%$ & 0 & 54.6649 & 25.595 & 0 & DRS(-) \\
\hline Lux & $100.0 \%$ & N/A & N/A & N/A & N/A & CRS(0) \\
\hline Malta & $101.4 \%$ & 0 & 0 & 0 & 0 & IRS(+) \\
\hline Netherl & $100.0 \%$ & N/A & N/A & N/A & N/A & $\mathrm{CRS}(0)$ \\
\hline Poland & $136.5 \%$ & 0 & 0 & .725764 & 0 & IRS(+) \\
\hline Portugal & $157.9 \%$ & 0 & 0 & 9.92103 & 0 & DRS(-) \\
\hline Romania & $150.0 \%$ & 0 & 0 & 4.86058 & 0 & $\operatorname{IRS}(+)$ \\
\hline Slovakia & $100.0 \%$ & N/A & N/A & N/A & N/A & IRS(+) \\
\hline Slovenia & $135.5 \%$ & 0 & 0 & 0 & 0 & IRS(+) \\
\hline Spain & $129.3 \%$ & 0 & 0 & 0 & 0 & IRS(+) \\
\hline Sweden & $100.0 \%$ & N/A & N/A & N/A & N/A & DRS(-) \\
\hline UK & $139.8 \%$ & 0 & 0 & 0 & 0 & IRS(+) \\
\hline
\end{tabular}

Source: own work. (N/A - for DMUs with 100\% efficiency coefficient no additional changes of inputs and/or outputs are offered)

Appendix 3. Results of DEA BCC output-oriented model for the EU28 in year 2012

\begin{tabular}{|c|c|c|c|c|c|c|}
\hline \multirow[b]{2}{*}{$\begin{array}{l}\text { DMU: } \\
\text { NUTS } 0\end{array}$} & \multirow[b]{2}{*}{$\begin{array}{c}\text { Efficiency } \\
\text { coefficient } \\
\Theta[\%]\end{array}$} & \multicolumn{2}{|c|}{$\begin{array}{c}\begin{array}{c}\text { Additional inputs reduction } \\
(\text { slacks s s }\end{array} \\
\end{array}$} & \multicolumn{2}{|c|}{$\begin{array}{c}\text { Additional output increase } \\
\text { (surpluses } \mathbf{s}^{+} \text {) }\end{array}$} & \multirow[b]{2}{*}{$\begin{array}{c}\text { returns to } \\
\text { scale: DRS(- } \\
\text { )-decreasing, } \\
\text { CRS(0) - } \\
\text { constant, } \\
\text { IRS(+) } \\
\text { increasing }\end{array}$} \\
\hline & & $\begin{array}{c}\text { R\&D } \\
\text { expenditure } \\
\text { in PPS per } \\
\text { economically } \\
\text { active } \\
\text { person at } \\
\text { constant } \\
2010 \text { prices } \\
(€ \text { PPS) }\end{array}$ & 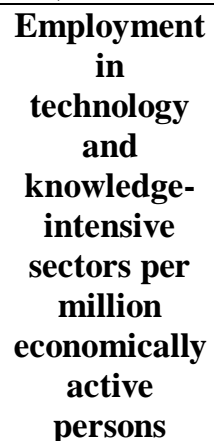 & $\begin{array}{l}\text { Number of } \\
\text { patent } \\
\text { applications } \\
\text { to the EPO } \\
\text { per million } \\
\text { economically } \\
\text { active } \\
\text { persons }\end{array}$ & $\begin{array}{c}\text { GDP PPS } \\
\text { per } \\
\text { economically } \\
\text { active } \\
\text { person at } \\
\text { constant } \\
2010 \text { prices } \\
(€ \text { PPS) }\end{array}$ & \\
\hline Austria & $117.0 \%$ & 0 & 15.1926 & 0 & 0 & DRS(-) \\
\hline Belgium & $127.0 \%$ & 0 & 0 & 0 & 0 & $\operatorname{IRS}(+)$ \\
\hline Bulgaria & $100.0 \%$ & N/A & N/A & N/A & N/A & IRS $(+)$ \\
\hline Croatia & $127.3 \%$ & 0 & 0 & .0204397 & 0 & IRS(+) \\
\hline Cyprus & $100.0 \%$ & N/A & N/A & N/A & N/A & $\mathrm{CRS}(0)$ \\
\hline Czech & $181.6 \%$ & 0 & 26.8135 & 19.8014 & 0 & DRS(-) \\
\hline Denmark & $114.8 \%$ & 0 & 0 & 0 & 0 & IRS(+) \\
\hline Estonia & $221.9 \%$ & 0 & 0 & 23.358 & 0 & IRS(+) \\
\hline Finland & $100.0 \%$ & N/A & N/A & N/A & N/A & CRS(0) \\
\hline
\end{tabular}




\begin{tabular}{|c|c|c|c|c|c|c|}
\hline France & $113.3 \%$ & 0 & 0 & 0 & 0 & IRS(+) \\
\hline Germany & $100.0 \%$ & N/A & N/A & N/A & N/A & DRS(-) \\
\hline Greece & $100.0 \%$ & N/A & N/A & N/A & N/A & IRS(+) \\
\hline Hungary & $149.1 \%$ & 0 & 0 & 0 & 0 & IRS(+) \\
\hline Ireland & $123.7 \%$ & 0 & 0 & 0 & 0 & IRS(+) \\
\hline Italy & $101.5 \%$ & 0 & 0 & 0 & 0 & IRS(+) \\
\hline Latvia & $100.0 \%$ & N/A & N/A & N/A & N/A & IRS(+) \\
\hline Lithuania & $143.9 \%$ & 0 & 0 & 0 & 0 & IRS(+) \\
\hline Lux & $100.0 \%$ & N/A & N/A & N/A & N/A & CRS(0) \\
\hline Malta & $121.5 \%$ & 0 & 46.8385 & 13.8669 & 0 & DRS(-) \\
\hline Netherl & $100.0 \%$ & N/A & N/A & N/A & N/A & CRS(0) \\
\hline Poland & $131.7 \%$ & 0 & 13.3248 & 0 & 0 & DRS(-) \\
\hline Portugal & $151.5 \%$ & 0 & 0 & 28.9367 & 0 & IRS(+) \\
\hline Romania & $100.0 \%$ & N/A & N/A & N/A & N/A & CRS(0) \\
\hline Slovakia & $133.5 \%$ & 0 & 0 & 3.27385 & 0 & IRS(+) \\
\hline Slovenia & $185.1 \%$ & 0 & 0 & 0 & 0 & IRS(+) \\
\hline Spain & $100.0 \%$ & N/A & N/A & N/A & N/A & IRS(+) \\
\hline Sweden & $100.0 \%$ & N/A & N/A & N/A & N/A & CRS(0) \\
\hline UK & $129.4 \%$ & 0 & 1.72095 & 0 & 0 & DRS(-) \\
\hline
\end{tabular}

Source: own work. (N/A - for DMUs with $100 \%$ efficiency coefficient no additional changes of inputs and/or outputs are offered)

Appendix 4. Results of DEA BCC output-oriented model for the EU28 in year 2014

\begin{tabular}{|c|c|c|c|c|c|c|}
\hline \multirow[b]{2}{*}{$\begin{array}{l}\text { DMU: } \\
\text { NUTS } 0\end{array}$} & \multirow[b]{2}{*}{$\begin{array}{c}\text { Efficiency } \\
\text { coefficient } \\
\Theta[\%]\end{array}$} & \multicolumn{2}{|c|}{$\begin{array}{c}\text { Additional inputs reduction } \\
(\text { (slacks s s-) }\end{array}$} & \multicolumn{2}{|c|}{$\begin{array}{c}\text { Additional output increase } \\
\left(\text { surpluses } \mathbf{s}^{+}\right)\end{array}$} & \multirow[b]{2}{*}{$\begin{array}{c}\text { returns to } \\
\text { scale: DRS(- } \\
\text { )-decreasing, } \\
\text { CRS(0) - } \\
\text { constant, } \\
\text { IRS(+) } \\
\text { increasing }\end{array}$} \\
\hline & & $\begin{array}{c}\text { R\&D } \\
\text { expenditure } \\
\text { in PPS per } \\
\text { economically } \\
\text { active } \\
\text { person at } \\
\text { constant } \\
2010 \text { prices } \\
(€ \text { PPS) }\end{array}$ & $\begin{array}{c}\text { Employment } \\
\text { in } \\
\text { technology } \\
\text { and } \\
\text { knowledge- } \\
\text { intensive } \\
\text { sectors per } \\
\text { million } \\
\text { economically } \\
\text { active } \\
\text { persons }\end{array}$ & $\begin{array}{l}\text { Number of } \\
\text { patent } \\
\text { applications } \\
\text { to the EPO } \\
\text { per million } \\
\text { economically } \\
\text { active } \\
\text { persons }\end{array}$ & $\begin{array}{c}\text { GDP PPS } \\
\text { per } \\
\text { economically } \\
\text { active } \\
\text { person at } \\
\text { constant } \\
2010 \text { prices } \\
\text { (€ PPS) }\end{array}$ & \\
\hline Austria & $123.8 \%$ & 92.6081 & 19.3605 & 0 & 0 & DRS(-) \\
\hline Belgium & $137.5 \%$ & 0 & 0 & 0 & 0 & IRS(+) \\
\hline Bulgaria & $162.9 \%$ & 0 & 36.287 & 0 & 0 & DRS(-) \\
\hline Croatia & $125.9 \%$ & 0 & 0 & 10.5029 & 0 & IRS(+) \\
\hline Cyprus & $100.0 \%$ & N/A & N/A & N/A & N/A & $\mathrm{CRS}(0)$ \\
\hline Czech & $171.7 \%$ & 0 & 58.1055 & 16.7864 & 0 & DRS(-) \\
\hline Denmark & $121.9 \%$ & 76.137 & 14.381 & 0 & 0 & DRS(-) \\
\hline Estonia & $180.3 \%$ & 0 & 67.5724 & 25.2245 & 0 & DRS(-) \\
\hline Finland & $100.0 \%$ & N/A & N/A & N/A & N/A & $\mathrm{CRS}(0)$ \\
\hline France & $121.4 \%$ & 0 & 0 & 0 & 0 & IRS(+) \\
\hline Germany & $117.5 \%$ & 0 & 27.7829 & 0 & 0 & DRS(-) \\
\hline Greece & $100.0 \%$ & N/A & N/A & N/A & N/A & $\operatorname{IRS}(+)$ \\
\hline Hungary & $148.7 \%$ & 0 & 62.9173 & 0 & 0 & DRS(-) \\
\hline Ireland & $128.1 \%$ & 0 & 0 & 0 & 0 & IRS(+) \\
\hline Italy & $103.4 \%$ & 0 & 0 & 0 & 0 & IRS(+) \\
\hline Latvia & $100.0 \%$ & N/A & N/A & N/A & N/A & IRS(+) \\
\hline Lithuania & $142.7 \%$ & 0 & 41.0644 & 0 & 0 & DRS(-) \\
\hline Lux & $100.0 \%$ & N/A & N/A & N/A & N/A & CRS(0) \\
\hline Malta & $120.3 \%$ & 0 & 85.6618 & 21.0444 & 0 & DRS(-) \\
\hline Netherl & $100.0 \%$ & N/A & N/A & N/A & N/A & CRS $(0)$ \\
\hline
\end{tabular}




\begin{tabular}{|c|c|c|c|c|c|c|}
\hline Poland & $128.2 \%$ & 0 & 60.0122 & 0 & 0 & DRS(-) \\
\hline Portugal & $147.7 \%$ & 0 & 0 & 19.3991 & 0 & IRS(+) \\
\hline Romania & $100.0 \%$ & N/A & N/A & N/A & N/A & CRS(0) \\
\hline Slovakia & $129.5 \%$ & 0 & 21.2088 & 13.1487 & 0 & DRS(-) \\
\hline Slovenia & $167.7 \%$ & 0 & 0 & 0 & 0 & IRS(+) \\
\hline Spain & $105.6 \%$ & 81.1889 & 0 & 0 & 0 & IRS(+) \\
\hline Sweden & $103.6 \%$ & 84.9246 & 6.12823 & 0 & 0 & DRS(-) \\
\hline UK & $136.6 \%$ & 0 & 39.7647 & 0 & 0 & DRS(-) \\
\hline
\end{tabular}

Source: own work. (N/A - for DMUs with $100 \%$ efficiency coefficient no additional changes of inputs and/or outputs are offered)

Appendix 5. Results of DEA BCC output-oriented model for EU NUTS 2 in year 2012

\begin{tabular}{|c|c|c|c|c|c|c|}
\hline \multirow[b]{2}{*}{$\begin{array}{l}\text { DMU: } \\
\text { NUTS } 2\end{array}$} & \multirow[b]{2}{*}{$\begin{array}{c}\text { Efficiency } \\
\text { coefficient } \\
\Theta[\%]\end{array}$} & \multicolumn{2}{|c|}{$\begin{array}{c}\text { Additional inputs reduction } \\
\left(\text { slacks s }{ }^{-}\right)\end{array}$} & \multicolumn{2}{|c|}{$\begin{array}{c}\text { Additional output increase } \\
\left(\text { surpluses } \mathbf{s}^{+}\right)\end{array}$} & \multirow[b]{2}{*}{$\begin{array}{c}\text { returns to } \\
\text { scale: DRS(- } \\
\text { )-decreasing. } \\
\text { CRS(0) - } \\
\text { constant. } \\
\text { IRS(+) } \\
\text { increasing }\end{array}$} \\
\hline & & $\begin{array}{c}\text { R\&D } \\
\text { expenditure } \\
\text { in PPS per } \\
\text { economically } \\
\text { active } \\
\text { person at } \\
\text { constant } \\
2010 \text { prices } \\
(€ \text { PPS) }\end{array}$ & $\begin{array}{c}\text { Employment } \\
\text { in } \\
\text { technology } \\
\text { and } \\
\text { knowledge- } \\
\text { intensive } \\
\text { sectors per } \\
\text { million } \\
\text { economically } \\
\text { active } \\
\text { persons } \\
\end{array}$ & $\begin{array}{c}\text { Number of } \\
\text { patent } \\
\text { applications } \\
\text { to the EPO } \\
\text { per million } \\
\text { economically } \\
\text { active } \\
\text { persons }\end{array}$ & $\begin{array}{c}\text { GDP PPS } \\
\text { per } \\
\text { economically } \\
\text { active } \\
\text { person at } \\
\text { constant } \\
2010 \text { prices } \\
\text { (€ PPS) }\end{array}$ & \\
\hline AT11 & $185.2 \%$ & 0 & 117.884 & 0 & 0 & CRS $(0)$ \\
\hline AT12 & $173.8 \%$ & 0 & 84.0204 & 0 & 0 & CRS(0) \\
\hline AT13 & $181.6 \%$ & 913.227 & 49.3794 & 0 & 0 & CRS $(0)$ \\
\hline AT21 & $238.2 \%$ & 0 & 117.885 & 0 & 0 & $\mathrm{CRS}(0)$ \\
\hline AT22 & $184.5 \%$ & 0 & 84.0205 & 0 & 0 & CRS(0) \\
\hline AT31 & $168.6 \%$ & 913.228 & 49.3795 & 0 & 0 & CRS $(0)$ \\
\hline AT32 & $151.8 \%$ & 0 & 117.886 & 0 & 0 & CRS $(0)$ \\
\hline AT33 & $190.3 \%$ & 0 & 84.0206 & 0 & 0 & CRS(0) \\
\hline AT34 & $100.0 \%$ & N/A & N/A & N/A & N/A & CRS $(0)$ \\
\hline BE10 & $115.9 \%$ & 0 & 117.887 & 0 & 0 & $\operatorname{IRS}(+)$ \\
\hline BE21 & $174.7 \%$ & 0 & 84.0207 & 0 & 0 & CRS(0) \\
\hline BE22 & $176.9 \%$ & 913.230 & 49.3797 & 0 & 0 & CRS $(0)$ \\
\hline BE23 & $212.5 \%$ & 0 & 117.888 & 0 & 0 & CRS $(0)$ \\
\hline BE24 & $158.4 \%$ & 0 & 84.0208 & 0 & 0 & CRS $(0)$ \\
\hline BE25 & $164.3 \%$ & 913.231 & 49.3798 & 0 & 0 & $\mathrm{CRS}(0)$ \\
\hline BE31 & $148.3 \%$ & 0 & 117.889 & 0 & 0 & IRS(+) \\
\hline BE32 & $208.7 \%$ & 0 & 84.0209 & 0 & 0 & $\mathrm{CRS}(0)$ \\
\hline BE33 & $183.9 \%$ & 913.232 & 49.3799 & 0 & 0 & CRS(0) \\
\hline BE34 & $100.0 \%$ & N/A & N/A & N/A & N/A & CRS $(0)$ \\
\hline BE35 & $176.5 \%$ & 0 & 84.0210 & 0 & 0 & $\mathrm{CRS}(0)$ \\
\hline BG31 & $157.2 \%$ & 913.233 & 49.3800 & 0 & 0 & IRS(+) \\
\hline BG32 & $100.0 \%$ & N/A & N/A & N/A & N/A & IRS(+) \\
\hline BG33 & $100.0 \%$ & N/A & N/A & N/A & N/A & IRS(+) \\
\hline BG34 & $157.3 \%$ & 913.234 & 49.3801 & 0 & 0 & IRS(+) \\
\hline BG41 & $769.6 \%$ & 0 & 117.892 & 0 & 0 & CRS(0) \\
\hline BG42 & $233.1 \%$ & 0 & 84.0212 & 0 & 0 & $\operatorname{IRS}(+)$ \\
\hline CY00 & $198.6 \%$ & 913.235 & 49.3802 & 0 & 0 & CRS $(0)$ \\
\hline CZ01 & $394.3 \%$ & 0 & 117.893 & 0 & 0 & CRS $(0)$ \\
\hline CZ02 & $516.8 \%$ & 0 & 84.0213 & 0 & 0 & CRS $(0)$ \\
\hline CZ03 & $565.0 \%$ & 913.236 & 49.3803 & 0 & 0 & CRS(0) \\
\hline CZ04 & $280.3 \%$ & 0 & 117.894 & 0 & 0 & IRS(+) \\
\hline
\end{tabular}




\begin{tabular}{|c|c|c|c|c|c|c|}
\hline CZ05 & $495.0 \%$ & 0 & 84.0214 & 0 & 0 & CRS(0) \\
\hline CZ06 & $550.8 \%$ & 913.237 & 49.3804 & 0 & 0 & CRS $(0)$ \\
\hline CZ07 & $566.9 \%$ & 0 & 117.895 & 0 & 0 & CRS(0) \\
\hline CZ08 & $520.6 \%$ & 0 & 84.0215 & 0 & 0 & CRS(0) \\
\hline DE11 & $112.4 \%$ & 913.238 & 49.3805 & 0 & 0 & CRS $(0)$ \\
\hline DE12 & $130.3 \%$ & 0 & 117.896 & 0 & 0 & CRS $(0)$ \\
\hline DE13 & $142.4 \%$ & 0 & 84.0216 & 0 & 0 & CRS(0) \\
\hline DE14 & $135.8 \%$ & 913.239 & 49.3806 & 0 & 0 & CRS $(0)$ \\
\hline DE21 & $108.7 \%$ & 0 & 117.897 & 0 & 0 & CRS $(0)$ \\
\hline DE22 & $167.6 \%$ & 0 & 84.0217 & 0 & 0 & CRS(0) \\
\hline DE23 & $120.5 \%$ & 913.240 & 49.3807 & 0 & 0 & CRS $(0)$ \\
\hline DE24 & $168.4 \%$ & 0 & 117.898 & 0 & 0 & CRS(0) \\
\hline DE25 & $116.8 \%$ & 0 & 84.0218 & 0 & 0 & CRS(0) \\
\hline DE26 & $149.9 \%$ & 913.241 & 49.3808 & 0 & 0 & CRS $(0)$ \\
\hline DE27 & $130.1 \%$ & 0 & 117.899 & 0 & 0 & CRS(0) \\
\hline DE30 & $209.0 \%$ & 0 & 84.0219 & 0 & 0 & CRS(0) \\
\hline DE40 & $217.9 \%$ & 913.242 & 49.3809 & 0 & 0 & CRS $(0)$ \\
\hline DE50 & $198.5 \%$ & 0 & 117.900 & 0 & 0 & CRS(0) \\
\hline DE60 & $139.8 \%$ & 0 & 84.0220 & 0 & 0 & CRS(0) \\
\hline DE71 & $150.4 \%$ & 913.243 & 49.3810 & 0 & 0 & CRS $(0)$ \\
\hline DE72 & $196.7 \%$ & 0 & 117.901 & 0 & 0 & CRS $(0)$ \\
\hline DE73 & $184.3 \%$ & 0 & 84.0221 & 0 & 0 & CRS(0) \\
\hline DE80 & $259.0 \%$ & 913.244 & 49.3811 & 0 & 0 & CRS(0) \\
\hline DE91 & $186.1 \%$ & 0 & 117.902 & 0 & 0 & CRS $(0)$ \\
\hline DE92 & $183.5 \%$ & 0 & 84.0222 & 0 & 0 & CRS $(0)$ \\
\hline DE93 & $171.1 \%$ & 913.245 & 49.3812 & 0 & 0 & CRS(0) \\
\hline DE94 & $144.3 \%$ & 0 & 117.903 & 0 & 0 & CRS $(0)$ \\
\hline DEA1 & $146.4 \%$ & 0 & 84.0223 & 0 & 0 & CRS $(0)$ \\
\hline DEA2 & $170.9 \%$ & 913.246 & 49.3813 & 0 & 0 & CRS(0) \\
\hline DEA3 & $145.6 \%$ & 0 & 117.904 & 0 & 0 & CRS $(0)$ \\
\hline DEA4 & $152.3 \%$ & 0 & 84.0224 & 0 & 0 & CRS $(0)$ \\
\hline DEA5 & $157.1 \%$ & 913.247 & 49.3814 & 0 & 0 & CRS(0) \\
\hline DEB1 & $138.2 \%$ & 0 & 117.905 & 0 & 0 & CRS $(0)$ \\
\hline DEB2 & $282.5 \%$ & 0 & 84.0225 & 0 & 0 & CRS(0) \\
\hline DEB3 & $157.3 \%$ & 913.248 & 49.3815 & 0 & 0 & CRS(0) \\
\hline DEC0 & $162.8 \%$ & 0 & 117.906 & 0 & 0 & CRS(0) \\
\hline DED2 & $276.6 \%$ & 0 & 84.0226 & 0 & 0 & CRS(0) \\
\hline DED4 & $286.7 \%$ & 913.249 & 49.3816 & 0 & 0 & CRS(0) \\
\hline DED5 & $224.6 \%$ & 0 & 117.907 & 0 & 0 & CRS $(0)$ \\
\hline DEE0 & $238.2 \%$ & 0 & 84.0227 & 0 & 0 & CRS(0) \\
\hline DEF0 & $175.3 \%$ & 913.250 & 49.3817 & 0 & 0 & CRS(0) \\
\hline DEG0 & $236.2 \%$ & 0 & 117.908 & 0 & 0 & CRS(0) \\
\hline DK01 & $150.4 \%$ & 0 & 84.0228 & 0 & 0 & IRS(+) \\
\hline DK02 & $176.2 \%$ & 913.251 & 49.3818 & 0 & 0 & CRS(0) \\
\hline DK03 & $155.7 \%$ & 0 & 117.909 & 0 & 0 & CRS(0) \\
\hline DK04 & $163.3 \%$ & 0 & 84.0229 & 0 & 0 & IRS(+) \\
\hline DK05 & $158.1 \%$ & 913.252 & 49.3819 & 0 & 0 & CRS(0) \\
\hline EE00 & $615.9 \%$ & 0 & 117.910 & 0 & 0 & CRS(0) \\
\hline EL11 & $233.9 \%$ & 0 & 84.0230 & 0 & 0 & $\operatorname{IRS}(+)$ \\
\hline EL12 & $234.5 \%$ & 913.253 & 49.3820 & 0 & 0 & IRS(+) \\
\hline EL13 & $143.1 \%$ & 0 & 117.911 & 0 & 0 & IRS(+) \\
\hline EL14 & $220.4 \%$ & 0 & 84.0231 & 0 & 0 & $\operatorname{IRS}(+)$ \\
\hline EL21 & $375.0 \%$ & 913.254 & 49.3821 & 0 & 0 & CRS(0) \\
\hline EL22 & $129.9 \%$ & 0 & 117.912 & 0 & 0 & IRS(+) \\
\hline EL23 & $339.6 \%$ & 0 & 84.0232 & 0 & 0 & CRS(0) \\
\hline EL24 & $112.9 \%$ & 913.255 & 49.3822 & 0 & 0 & IRS(+) \\
\hline EL25 & $173.7 \%$ & 0 & 117.913 & 0 & 0 & IRS(+) \\
\hline EL30 & $170.8 \%$ & 0 & 84.0233 & 0 & 0 & IRS(+) \\
\hline
\end{tabular}




\begin{tabular}{|c|c|c|c|c|c|c|}
\hline EL41 & $278.8 \%$ & 913.256 & 49.3823 & 0 & 0 & IRS(+) \\
\hline EL42 & $100.0 \%$ & N/A & N/A & N/A & N/A & IRS(+) \\
\hline EL43 & $245.5 \%$ & 0 & 84.0234 & 0 & 0 & IRS(+) \\
\hline ES11 & $247.9 \%$ & 913.257 & 49.3824 & 0 & 0 & IRS(+) \\
\hline ES12 & $216.2 \%$ & 0 & 117.915 & 0 & 0 & IRS(+) \\
\hline ES13 & $255.0 \%$ & 0 & 84.0235 & 0 & 0 & IRS(+) \\
\hline ES21 & $231.0 \%$ & 913.258 & 49.3825 & 0 & 0 & IRS(+) \\
\hline ES22 & $222.2 \%$ & 0 & 117.916 & 0 & 0 & IRS(+) \\
\hline ES23 & $191.6 \%$ & 0 & 84.0236 & 0 & 0 & IRS(+) \\
\hline ES24 & $183.3 \%$ & 913.259 & 49.3826 & 0 & 0 & IRS(+) \\
\hline ES30 & $220.0 \%$ & 0 & 117.917 & 0 & 0 & IRS(+) \\
\hline ES41 & $247.5 \%$ & 0 & 84.0237 & 0 & 0 & IRS(+) \\
\hline ES42 & $119.2 \%$ & 913.260 & 49.3827 & 0 & 0 & IRS(+) \\
\hline ES43 & $100.0 \%$ & N/A & N/A & N/A & N/A & IRS(+) \\
\hline ES51 & $161.0 \%$ & 0 & 84.0238 & 0 & 0 & IRS(+) \\
\hline ES52 & $178.2 \%$ & 913.261 & 49.3828 & 0 & 0 & IRS(+) \\
\hline ES53 & $144.3 \%$ & 0 & 117.919 & 0 & 0 & IRS(+) \\
\hline ES61 & $100.0 \%$ & N/A & N/A & N/A & N/A & IRS(+) \\
\hline ES62 & $180.2 \%$ & 913.262 & 49.3829 & 0 & 0 & IRS(+) \\
\hline FI19 & $168.1 \%$ & 0 & 117.920 & 0 & 0 & IRS(+) \\
\hline FI1B & $118.5 \%$ & 0 & 84.0240 & 0 & 0 & IRS(+) \\
\hline FI1C & $192.1 \%$ & 913.263 & 49.3830 & 0 & 0 & IRS(+) \\
\hline FI1D & $204.6 \%$ & 0 & 117.921 & 0 & 0 & IRS(+) \\
\hline FI20 & $100.0 \%$ & N/A & N/A & N/A & N/A & CRS $(0)$ \\
\hline $\begin{array}{l}\text { FR10 } \\
\end{array}$ & $142.6 \%$ & 913.264 & 49.3831 & 0 & 0 & IRS(+) \\
\hline FR21 & $152.5 \%$ & 0 & 117.922 & 0 & 0 & CRS $(0)$ \\
\hline FR22 & $203.9 \%$ & 0 & 84.0242 & 0 & 0 & CRS $(0)$ \\
\hline FR23 & $173.2 \%$ & 913.265 & 49.3832 & 0 & 0 & CRS $(0)$ \\
\hline FR24 & $191.5 \%$ & 0 & 117.923 & 0 & 0 & CRS(0) \\
\hline FR25 & $197.2 \%$ & 0 & 84.0243 & 0 & 0 & $\mathrm{CRS}(0)$ \\
\hline FR26 & $173.9 \%$ & 913.266 & 49.3833 & 0 & 0 & $\operatorname{CRS}(0)$ \\
\hline FR30 & $176.4 \%$ & 0 & 117.924 & 0 & 0 & CRS $(0)$ \\
\hline FR41 & $198.8 \%$ & 0 & 84.0244 & 0 & 0 & CRS $(0)$ \\
\hline FR42 & $178.7 \%$ & 913.267 & 49.3834 & 0 & 0 & CRS $(0)$ \\
\hline FR43 & $238.2 \%$ & 0 & 117.925 & 0 & 0 & IRS(+) \\
\hline FR51 & $179.5 \%$ & 0 & 84.0245 & 0 & 0 & CRS $(0)$ \\
\hline FR52 & $194.5 \%$ & 913.268 & 49.3835 & 0 & 0 & CRS $(0)$ \\
\hline FR53 & $179.5 \%$ & 0 & 117.926 & 0 & 0 & $\mathrm{CRS}(0)$ \\
\hline FR61 & $197.7 \%$ & 0 & 84.0246 & 0 & 0 & $\operatorname{CRS}(0)$ \\
\hline FR62 & $259.0 \%$ & 913.269 & 49.3836 & 0 & 0 & CRS $(0)$ \\
\hline FR63 & $187.6 \%$ & 0 & 117.927 & 0 & 0 & CRS(0) \\
\hline FR71 & $166.9 \%$ & 0 & 84.0247 & 0 & 0 & IRS(+) \\
\hline FR72 & $216.1 \%$ & 913.270 & 49.3837 & 0 & 0 & IRS(+) \\
\hline FR81 & $227.1 \%$ & 0 & 117.928 & 0 & 0 & IRS(+) \\
\hline FR82 & $205.8 \%$ & 0 & 84.0248 & 0 & 0 & CRS $(0)$ \\
\hline FR83 & $100.0 \%$ & N/A & N/A & N/A & N/A & CRS $(0)$ \\
\hline HU10 & $408.0 \%$ & 0 & 117.929 & 0 & 0 & CRS(0) \\
\hline HU21 & $615.9 \%$ & 0 & 84.0249 & 0 & 0 & $\mathrm{CRS}(0)$ \\
\hline HU22 & $442.8 \%$ & 913.272 & 49.3839 & 0 & 0 & CRS $(0)$ \\
\hline HU23 & $645.0 \%$ & 0 & 117.930 & 0 & 0 & CRS $(0)$ \\
\hline HU31 & $461.6 \%$ & 0 & 84.0250 & 0 & 0 & IRS(+) \\
\hline HU32 & $740.7 \%$ & 913.273 & 49.3840 & 0 & 0 & IRS(+) \\
\hline HU33 & $584.0 \%$ & 0 & 117.931 & 0 & 0 & IRS(+) \\
\hline IE01 & $199.7 \%$ & 0 & 84.0251 & 0 & 0 & IRS(+) \\
\hline IE02 & $171.8 \%$ & 913.274 & 49.3841 & 0 & 0 & CRS $(0)$ \\
\hline ITC1 & $213.1 \%$ & 0 & 117.932 & 0 & 0 & CRS $(0)$ \\
\hline ITC2 & $135.1 \%$ & 0 & 84.0252 & 0 & 0 & CRS $(0)$ \\
\hline ITC3 & $186.3 \%$ & 913.275 & 49.3842 & 0 & 0 & $\operatorname{CRS}(0)$ \\
\hline
\end{tabular}




\begin{tabular}{|c|c|c|c|c|c|c|}
\hline ITC4 & $165.3 \%$ & 0 & 117.933 & 0 & 0 & CRS(0) \\
\hline ITF1 & $201.7 \%$ & 0 & 84.0253 & 0 & 0 & CRS $(0)$ \\
\hline ITF2 & $184.6 \%$ & 913.276 & 49.3843 & 0 & 0 & CRS $(0)$ \\
\hline ITF3 & $240.3 \%$ & 0 & 117.934 & 0 & 0 & IRS(+) \\
\hline ITF4 & $233.5 \%$ & 0 & 84.0254 & 0 & 0 & CRS $(0)$ \\
\hline ITF5 & $207.9 \%$ & 913.277 & 49.3844 & 0 & 0 & CRS $(0)$ \\
\hline ITF6 & $215.1 \%$ & 0 & 117.935 & 0 & 0 & IRS(+) \\
\hline ITG1 & $230.1 \%$ & 0 & 84.0255 & 0 & 0 & IRS(+) \\
\hline ITG2 & $239.7 \%$ & 913.278 & 49.3845 & 0 & 0 & CRS $(0)$ \\
\hline ITH1 & $119.9 \%$ & 0 & 117.936 & 0 & 0 & CRS(0) \\
\hline ITH2 & $214.2 \%$ & 0 & 84.0256 & 0 & 0 & CRS $(0)$ \\
\hline ITH3 & $163.0 \%$ & 913.279 & 49.3846 & 0 & 0 & CRS $(0)$ \\
\hline ITH4 & $145.5 \%$ & 0 & 117.937 & 0 & 0 & CRS(0) \\
\hline ITH5 & $178.0 \%$ & 0 & 84.0257 & 0 & 0 & CRS $(0)$ \\
\hline ITI1 & $189.4 \%$ & 913.280 & 49.3847 & 0 & 0 & CRS $(0)$ \\
\hline ITI2 & $199.1 \%$ & 0 & 117.938 & 0 & 0 & CRS(0) \\
\hline ITI3 & $180.6 \%$ & 0 & 84.0258 & 0 & 0 & CRS $(0)$ \\
\hline ITI4 & $211.6 \%$ & 913.281 & 49.3848 & 0 & 0 & CRS(0) \\
\hline LT00 & $540.6 \%$ & 0 & 117.939 & 0 & 0 & CRS(0) \\
\hline LU00 & $114.7 \%$ & 0 & 84.0259 & 0 & 0 & CRS $(0)$ \\
\hline LV00 & $407.8 \%$ & 913.282 & 49.3849 & 0 & 0 & IRS(+) \\
\hline MT00 & $288.3 \%$ & 0 & 117.940 & 0 & 0 & CRS $(0)$ \\
\hline NL11 & $172.1 \%$ & 0 & 84.0260 & 0 & 0 & CRS(0) \\
\hline NL12 & $195.4 \%$ & 913.283 & 49.3850 & 0 & 0 & CRS $(0)$ \\
\hline NL13 & $189.8 \%$ & 0 & 117.941 & 0 & 0 & CRS $(0)$ \\
\hline NL21 & $197.3 \%$ & 0 & 84.0261 & 0 & 0 & CRS(0) \\
\hline NL22 & $228.2 \%$ & 913.284 & 49.3851 & 0 & 0 & CRS $(0)$ \\
\hline NL23 & $231.2 \%$ & 0 & 117.942 & 0 & 0 & CRS $(0)$ \\
\hline NL31 & $192.4 \%$ & 0 & 84.0262 & 0 & 0 & CRS(0) \\
\hline NL32 & $189.5 \%$ & 913.285 & 49.3852 & 0 & 0 & CRS $(0)$ \\
\hline NL33 & $190.1 \%$ & 0 & 117.943 & 0 & 0 & CRS $(0)$ \\
\hline NL34 & $156.6 \%$ & 0 & 84.0263 & 0 & 0 & CRS(0) \\
\hline NL41 & $112.0 \%$ & 913.286 & 49.3853 & 0 & 0 & IRS(+) \\
\hline NL42 & $180.9 \%$ & 0 & 117.944 & 0 & 0 & CRS(0) \\
\hline PL11 & $477.1 \%$ & 0 & 84.0264 & 0 & 0 & IRS(+) \\
\hline PL12 & $403.1 \%$ & 913.287 & 49.3854 & 0 & 0 & CRS(0) \\
\hline PL21 & $517.6 \%$ & 0 & 117.945 & 0 & 0 & CRS $(0)$ \\
\hline PL22 & $429.0 \%$ & 0 & 84.0265 & 0 & 0 & CRS(0) \\
\hline PL31 & $709.6 \%$ & 913.288 & 49.3855 & 0 & 0 & CRS $(0)$ \\
\hline PL32 & $646.8 \%$ & 0 & 117.946 & 0 & 0 & CRS $(0)$ \\
\hline PL33 & $252.7 \%$ & 0 & 84.0266 & 0 & 0 & IRS(+) \\
\hline PL34 & $334.1 \%$ & 913.289 & 49.3856 & 0 & 0 & IRS(+) \\
\hline PL41 & $449.5 \%$ & 0 & 117.947 & 0 & 0 & CRS $(0)$ \\
\hline PL42 & $292.6 \%$ & 0 & 84.0267 & 0 & 0 & IRS(+) \\
\hline PL43 & $166.9 \%$ & 913.290 & 49.3857 & 0 & 0 & IRS(+) \\
\hline PL51 & $392.0 \%$ & 0 & 117.948 & 0 & 0 & CRS $(0)$ \\
\hline $\begin{array}{l}\text { PL52 } \\
\end{array}$ & $171.5 \%$ & 0 & 84.0268 & 0 & 0 & IRS(+) \\
\hline PL61 & $340.4 \%$ & 913.291 & 49.3858 & 0 & 0 & IRS(+) \\
\hline $\begin{array}{l}\text { PL62 } \\
\end{array}$ & $384.1 \%$ & 0 & 117.949 & 0 & 0 & IRS(+) \\
\hline $\begin{array}{l}\text { PL63 } \\
\end{array}$ & $483.3 \%$ & 0 & 84.0269 & 0 & 0 & CRS $(0)$ \\
\hline PT11 & $457.9 \%$ & 913.292 & 49.3859 & 0 & 0 & CRS $(0)$ \\
\hline PT15 & $219.0 \%$ & 0 & 117.950 & 0 & 0 & IRS(+) \\
\hline $\begin{array}{l}\text { PT16 } \\
\end{array}$ & $423.6 \%$ & 0 & 84.0270 & 0 & 0 & CRS $(0)$ \\
\hline PT17 & $324.8 \%$ & 913.293 & 49.3860 & 0 & 0 & IRS(+) \\
\hline PT18 & $247.3 \%$ & 0 & 117.951 & 0 & 0 & $\operatorname{IRS}(+)$ \\
\hline RO11 & $501.4 \%$ & 0 & 84.0271 & 0 & 0 & CRS $(0)$ \\
\hline RO12 & $261.1 \%$ & 913.294 & 49.3861 & 0 & 0 & CRS(0) \\
\hline RO21 & $456.6 \%$ & 0 & 117.952 & 0 & 0 & CRS $(0)$ \\
\hline
\end{tabular}




\begin{tabular}{|c|c|c|c|c|c|c|}
\hline RO22 & $100.0 \%$ & N/A & N/A & N/A & N/A & CRS(0) \\
\hline RO31 & $529.3 \%$ & 913.295 & 49.3862 & 0 & 0 & $\operatorname{IRS}(+)$ \\
\hline RO32 & $535.9 \%$ & 0 & 117.953 & 0 & 0 & CRS $(0)$ \\
\hline RO41 & $145.4 \%$ & 0 & 84.0273 & 0 & 0 & CRS(0) \\
\hline RO42 & $299.1 \%$ & 913.296 & 49.3863 & 0 & 0 & CRS(0) \\
\hline SE11 & $110.2 \%$ & 0 & 117.954 & 0 & 0 & IRS(+) \\
\hline SE12 & $166.0 \%$ & 0 & 84.0274 & 0 & 0 & IRS(+) \\
\hline SE21 & $152.7 \%$ & 913.297 & 49.3864 & 0 & 0 & CRS(0) \\
\hline SE22 & $116.2 \%$ & 0 & 117.955 & 0 & 0 & IRS(+) \\
\hline SE23 & $183.6 \%$ & 0 & 84.0275 & 0 & 0 & CRS(0) \\
\hline SE31 & $148.3 \%$ & 913.298 & 49.3865 & 0 & 0 & CRS(0) \\
\hline SE32 & $131.1 \%$ & 0 & 117.956 & 0 & 0 & CRS(0) \\
\hline SE33 & $187.4 \%$ & 0 & 84.0276 & 0 & 0 & CRS(0) \\
\hline SI01 & $394.8 \%$ & 913.299 & 49.3866 & 0 & 0 & CRS(0) \\
\hline SI02 & $365.7 \%$ & 0 & 117.957 & 0 & 0 & CRS(0) \\
\hline SK01 & $370.9 \%$ & 0 & 84.0277 & 0 & 0 & CRS(0) \\
\hline SK02 & $251.4 \%$ & 913.300 & 49.3867 & 0 & 0 & IRS(+) \\
\hline SK03 & $418.1 \%$ & 0 & 117.958 & 0 & 0 & IRS(+) \\
\hline SK04 & $413.9 \%$ & 0 & 84.0278 & 0 & 0 & IRS(+) \\
\hline UKC1 & $193.2 \%$ & 913.301 & 49.3868 & 0 & 0 & CRS(0) \\
\hline UKC2 & $176.0 \%$ & 0 & 117.959 & 0 & 0 & CRS(0) \\
\hline UKD1 & $164.4 \%$ & 0 & 84.0279 & 0 & 0 & CRS(0) \\
\hline UKD3 & $165.9 \%$ & 913.302 & 49.3869 & 0 & 0 & CRS(0) \\
\hline UKD4 & $192.1 \%$ & 0 & 117.960 & 0 & 0 & CRS(0) \\
\hline UKD6 & $242.1 \%$ & 0 & 84.0280 & 0 & 0 & CRS $(0)$ \\
\hline UKD7 & $201.8 \%$ & 913.303 & 49.3870 & 0 & 0 & CRS(0) \\
\hline UKE1 & $174.5 \%$ & 0 & 117.961 & 0 & 0 & CRS(0) \\
\hline UKE2 & $201.7 \%$ & 0 & 84.0281 & 0 & 0 & CRS $(0)$ \\
\hline UKE3 & $201.9 \%$ & 913.304 & 49.3871 & 0 & 0 & CRS(0) \\
\hline UKE4 & $164.6 \%$ & 0 & 117.962 & 0 & 0 & CRS(0) \\
\hline UKF1 & $235.2 \%$ & 0 & 84.0282 & 0 & 0 & CRS(0) \\
\hline UKF2 & $177.8 \%$ & 913.305 & 49.3872 & 0 & 0 & CRS(0) \\
\hline UKF3 & $117.8 \%$ & 0 & 117.963 & 0 & 0 & IRS(+) \\
\hline UKG1 & $255.0 \%$ & 0 & 84.0283 & 0 & 0 & CRS(0) \\
\hline UKG2 & $162.2 \%$ & 913.306 & 49.3873 & 0 & 0 & CRS(0) \\
\hline UKG3 & $175.3 \%$ & 0 & 117.964 & 0 & 0 & CRS(0) \\
\hline UKH1 & $224.5 \%$ & 0 & 84.0284 & 0 & 0 & CRS(0) \\
\hline UKH2 & $225.8 \%$ & 913.307 & 49.3874 & 0 & 0 & CRS(0) \\
\hline UKH3 & $211.7 \%$ & 0 & 117.965 & 0 & 0 & CRS(0) \\
\hline UKI1 & $100.0 \%$ & N/A & N/A & N/A & N/A & CRS(0) \\
\hline UKI2 & $165.6 \%$ & 913.308 & 49.3875 & 0 & 0 & CRS(0) \\
\hline UKJ1 & $166.3 \%$ & 0 & 117.966 & 0 & 0 & CRS(0) \\
\hline UKJ2 & $162.7 \%$ & 0 & 84.0286 & 0 & 0 & CRS(0) \\
\hline UKJ3 & $213.6 \%$ & 913.309 & 49.3876 & 0 & 0 & CRS(0) \\
\hline UKJ4 & $223.5 \%$ & 0 & 117.967 & 0 & 0 & CRS(0) \\
\hline UKK1 & $191.4 \%$ & 0 & 84.0287 & 0 & 0 & CRS(0) \\
\hline UKK2 & $155.3 \%$ & 913.310 & 49.3877 & 0 & 0 & CRS(0) \\
\hline UKK3 & $100.0 \%$ & N/A & N/A & N/A & N/A & CRS(0) \\
\hline UKK4 & $173.5 \%$ & 0 & 84.0288 & 0 & 0 & CRS(0) \\
\hline UKL1 & $185.9 \%$ & 913.311 & 49.3878 & 0 & 0 & CRS(0) \\
\hline UKL2 & $191.8 \%$ & 0 & 117.969 & 0 & 0 & CRS(0) \\
\hline UKM2 & $170.1 \%$ & 0 & 84.0289 & 0 & 0 & CRS(0) \\
\hline UKM3 & $207.2 \%$ & 913.312 & 49.3879 & 0 & 0 & CRS(0) \\
\hline UKM5 & $161.4 \%$ & 0 & 117.970 & 0 & 0 & CRS(0) \\
\hline UKM6 & $181.1 \%$ & 0 & 84.0290 & 0 & 0 & CRS(0) \\
\hline UKNO & $205.0 \%$ & 913.313 & 49.3880 & 0 & 0 & CRS(0) \\
\hline
\end{tabular}


Source: own work. (N/A - for DMUs with 100\% efficiency coefficient no additional changes of inputs and/or outputs are offered) 